\title{
Article \\ Effects of Modified Atmosphere Packaging, Storage Temperature, and Absorbent Pads on the Quality of Fresh Cape Hake Fish Fillets
}

\author{
Umezuruike Linus Opara ${ }^{1,2, *(\mathbb{D}}$, Tobi Fadiji ${ }^{1}{ }^{(\mathbb{C}}$, Oluwafemi James Caleb ${ }^{1,3(\mathbb{C}}$ and Adebanji Olasupo Oluwole ${ }^{1}$ \\ 1 SARChI Postharvest Technology Research Laboratory, Africa Institute for Postharvest Technology, Faculty of \\ AgriSciences, Stellenbosch University, Stellenbosch 7602, South Africa; fadiji@sun.ac.za (T.F.); \\ oluwafemi@sun.ac.za (O.J.C.); astsupo@yahoo.com (A.O.O.) \\ 2 UNESCO International Centre for Biotechnology, Nsukka 410001, Enugu State, Nigeria \\ 3 Department of Food Science, Faculty of AgriSciences, Stellenbosch University, Stellenbosch 7602, South Africa \\ * Correspondence: opara@sun.ac.za
}

Citation: Opara, U.L.; Fadiji, T.; Caleb, O.J.; Oluwole, A.O. Effects of Modified Atmosphere Packaging, Storage Temperature, and Absorbent Pads on the Quality of Fresh Cape Hake Fish Fillets. Coatings 2022, 12, 310. https://doi.org/10.3390/ coatings 12030310

Academic Editor: Raffaele Porta

Received: 24 November 2021

Accepted: 2 February 2022

Published: 25 February 2022

Publisher's Note: MDPI stays neutral with regard to jurisdictional claims in published maps and institutional affiliations.

Copyright: (C) 2022 by the authors. Licensee MDPI, Basel, Switzerland. This article is an open access article distributed under the terms and conditions of the Creative Commons Attribution (CC BY) license (https:// creativecommons.org/licenses/by/ $4.0 /)$.

\begin{abstract}
This study investigated the effects of modified atmosphere packaging (MAP), storage temperature, and the use of absorbent pads (PAD) on the quality attributes of Cape hake (Merluccius capensis) fish fillets. Fresh Cape hake fillets were packaged under active-MA $\left(40 \% \mathrm{CO}_{2}+30 \% \mathrm{O}_{2}+30 \% \mathrm{~N}_{2}\right)$ or passive-MA $\left(0.039 \% \mathrm{CO}_{2}+20.95 \% \mathrm{O}_{2}+78 \% \mathrm{~N}_{2}\right)$, with and without PAD, and stored $0{ }^{\circ} \mathrm{C}, 4{ }^{\circ} \mathrm{C}$, and $8{ }^{\circ} \mathrm{C}$ (to mimic abuse temperature). The control fresh fillets were stored under passive-MAP without PAD at $0{ }^{\circ} \mathrm{C}, 4^{\circ} \mathrm{C}$, and $8{ }^{\circ} \mathrm{C}$. Headspace $\mathrm{O}_{2}$ gas composition continuously decreased below critical limits under passive-MAP, with an increase in storage temperature. Similarly, $\mathrm{O}_{2}$ levels decreased under active-MAP but did not reach critical levels, with the lowest being $9.5 \%$ at $0{ }^{\circ} \mathrm{C}$. The interaction of storage temperature and modified atmosphere had a significant effect on quality attributes of Cape hake fillets. Drip loss was higher in active-MAP packaged fillets without PAD (0.64\%) than passive-MAP packaged fillets without PAD $(0.27 \%)$. Drip loss was significantly reduced when using absorbent pads $(p<0.05)$. Firmness, color, and $\mathrm{pH}$ were better maintained under active-MAP at the lowest temperature of $0{ }^{\circ} \mathrm{C}$. Firmness (work of shear) of active-MA packaged fillets on day 12 at $0{ }^{\circ} \mathrm{C}$ and $4{ }^{\circ} \mathrm{C}$ was $527 \mathrm{~N} / \mathrm{s}$ and $506 \mathrm{~N} / \mathrm{s}$, respectively. Fillets packaged under active-MAP at $0{ }^{\circ} \mathrm{C}$ had longer shelf-life than control passive-MAP fillets.
\end{abstract}

Keywords: Cape hake; fish fillets; modified atmosphere packaging; absorbent pads; storage temperature

\section{Introduction}

Cape hake is a lean fish rich in poly-unsaturated fatty acids (PUFAs), such as omega-3 fatty acids, eicosapentaenoic (EPA) acid, and docosahexaenoic acid [1,2]. These fatty acids have been reported to increase fish nutritional value and guard against disease conditions in humans [2-4]. Poly-unsaturated fatty acids have been reported to lower blood pressure and cholesterol levels in humans [5-8]. Due to its high protein content, fish is regarded as a healthy alternative to fatty meat products, making it advantageous in reducing the occurrence of non-communicable illnesses such as heart attacks and strokes $[3,7,9]$.

Generally, fish is a high-quality product with considerable economic importance and accounts for about $17 \%$ of the global population's intake of animal protein [10-12]. However, only around $60 \%$ of palatable fish is utilized by end-users, with the remainder being converted into animal feed or lost [13]. Post-harvest loss due to decay is 10-12 million tonnes annually and this is estimated as $10 \%$ of the total global captured and cultured fish $[13,14]$. Post-harvest losses of fish are a matter of great importance to the fishing industry [15]. Researchers have proposed numerous post-harvest solutions to maintain the fish quality after harvest, extend shelf-life, and increase the marketability of fresh fish [15]. These include salting, drying, smoking, cold storage, frying, and innovative packaging [15-17].

Due to a shift in consumer lifestyles globally, there is an increase in the demand for fresh ready-to-cook (RTC) fish and fishery products $[6,18,19]$. Modified atmospheres 
packaging (MAP) combined with optimum cold storage offers the possibility to inhibit the normal spoilage flora and extend the shelf-life of fish and fishery products $[3,15,20-26]$. This involves changing the proportions of gases in a food package by withdrawing $\mathrm{O}_{2}$ or by replacing the atmosphere with a controlled mixture of gases, such as carbon dioxide $\left(\mathrm{CO}_{2}\right)$ and nitrogen $\left(\mathrm{N}_{2}\right)$ [27].

Erkan et al. [21] reported that active-modified atmospheres packaging $\left(70 \% \mathrm{CO}_{2}+5 \%\right.$ $\mathrm{O}_{2}+25 \% \mathrm{~N}_{2}$ ) and vacuum packaging (VP) extended the shelf-life of chub mackerel stored at $4{ }^{\circ} \mathrm{C}$ for 12 and 9 days, respectively. Lauzon et al. [23] indicted that the aerobic mesophillic bacteria were lower in cod fillets stored at $-2{ }^{\circ} \mathrm{C}$, in contrast to those stored at $0{ }^{\circ} \mathrm{C}$, and MA packaged fillets had a shelf-life of about 15 days at $0{ }^{\circ} \mathrm{C}$ and 21 days at $-2{ }^{\circ} \mathrm{C}$. Moreover, the use of active-MAP $\left(\mathrm{A}=40 \% \mathrm{CO}_{2}+30 \% \mathrm{O}_{2}+30 \% \mathrm{~N}_{2} ; \mathrm{B}=50 \% \mathrm{CO}_{2}+50 \% \mathrm{O}_{2}\right.$; and $\mathrm{C}=95 \% \mathrm{CO}_{2}+0 \% \mathrm{O}_{2}$ ) at $4{ }^{\circ} \mathrm{C}$ combined with natural preservatives on blue fish burger (mackerel and hake) led to lower aerobic mesophillic bacteria in fillets when compared to air-packed fillets at day 28 [3].

Similarly, the effects of vacuum and modified atmospheres on textural parameters and structural proteins of cultured meagre (Argyrosomus regius) fillets were studied by Sáez et al. [28]. Hernández et al. [29] evaluated the influence of modified atmosphere in packing sous vide of pirarucu in tucupi and shrimp sauce under refrigeration. Lekjing and Venkatachalam [27] explored the impact of MAP on the qualitative changes of pasteurized oysters. Zhang et al. [30] investigated the effect of air packaging, vacuum packaging, and MAP $\left(75 \% \mathrm{CO}_{2}+25 \% \mathrm{~N}_{2}\right)$ on the microbial composition and quality of lightly salted grass carp. Lázaro et al. [31] studied the combined effect of MAP $\left(50 \% \mathrm{CO}_{2}+50 \% \mathrm{~N}_{2}\right)$ and ultraviolet radiation type C $\left(\mathrm{UV}-\mathrm{C} ; 0.30 \mathrm{~J} / \mathrm{cm}^{2}\right)$ on the reduction of Salmonella typhimurium and E. coli O157:H7 in tilapia fillets. The impact of Ar and $\mathrm{N}_{2}$ used individually for MAP on the chemical, sensory, and microbiological qualities of refrigerated Asian sea bass slices was studied by Olatunde et al. [32]. Wang et al. [33] evaluated the influence of nitric oxide (NO)-MAP on the quality of tilapia fillets. Esteves et al. [34] assessed the impact of different packaging types (in air (AIR), vacuum (VP), and MAP) on the physicochemical, microbiological, and sensory qualities, as well as the shelf-life of gray triggerfish fillets stored at refrigeration temperature for 15 days. Although the use of MAP is a widely used and established technology, there is little or no information available related to its combined effects with absorbent pads and storage temperature on the quality attributes of Cape hake fish. Therefore, this study investigated the effects of MAP combined with absorbent pads and storage temperatures on the physicochemical, microbiological, and sensory quality attributes of Cape hake fish.

\section{Materials and Methods}

\subsection{Preparation of Fish Samples and Packaging}

Fresh Cape hake fillets (average weight of $200 \mathrm{~g}$ ) were purchased from a local retail market in Stellenbosch, South Africa. Fillets were iced with an appropriate quantity of ice (with 1:3 parts $w / w$ flake/ice) and packed in sterile padded polystyrene boxes. The fillets were collected approximately $18 \mathrm{~h}$ after cutting and transported in an air-conditioned and ventilated vehicle to the Postharvest Research Laboratory at Stellenbosch University, Stellenbosch, South Africa, within $15 \mathrm{~min}$. On arrival, the fish fillets were kept on ice and packaged into the following treatments: active-MAP $\left(40 \% \mathrm{CO}_{2}+30 \% \mathrm{O}_{2}+30 \% \mathrm{~N}_{2}\right)$ with and without (control) absorbent pads, and passive-MAP $\left(0.039 \% \mathrm{CO}_{2}+20.95 \% \mathrm{O}_{2}+78 \% \mathrm{~N}_{2}\right)$ with and without (control) absorbent pads.

All fish samples were packaged in polyethylene terephthalate (PET) trays with dimensions of $280 \mathrm{~mm} \times 190 \mathrm{~mm}$ (Zibo containers (Pty.) Ltd., Kuilsrivier, South Africa) and heat sealed with bi-axially oriented polyester film $\left(\mathrm{O}_{2}\right.$ permeability: $75 \mathrm{~cm}^{3}$ at $23{ }^{\circ} \mathrm{C}, 70 \% \mathrm{RH} \mathrm{bar}{ }^{-1}$; water vapor permeability: $2 \mathrm{~g} \mathrm{~d}^{-1}$ at $38^{\circ} \mathrm{C}, 90 \% \mathrm{RH}$ ) from Knilam Packaging (Pty.) Ltd., Cape Town, South Africa. A total of 380 packages were used in this study. Modified atmosphere packaging was performed using a Multivac packaging machine (Multivac Traysealer T100, Sepp Hagenuller GmbH \& Co.KG, Wolfertschwenden, Germany) and food grade gases from 


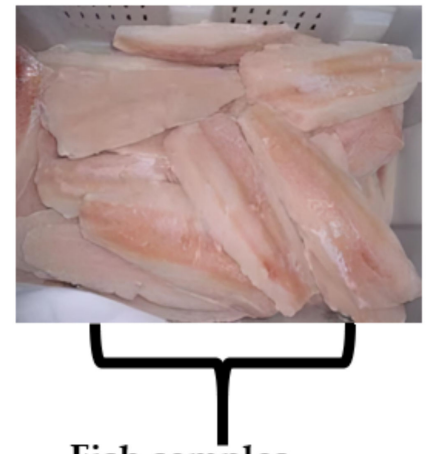

Fish samples
Air products Pty., Kempton Park, South Africa, as well as absorbent pads (Dri-Fresh ${ }^{\circledR}$, Sirane Ltd., Telford, Shropshire, UK). Figure 1 depicts the fish samples, packing procedure, and packaged fish fillet. The absorbent pads were made of an inert hygroscopic material according to the manufacturer's specification. Packaged fillets were then stored at $0{ }^{\circ} \mathrm{C}, 4{ }^{\circ} \mathrm{C}$, and $8^{\circ} \mathrm{C} \pm 0.5^{\circ} \mathrm{C}$ for 15 days. Samples for analyses were taken on days $0,3,6,9,12$, and 15 from each respective storage temperature. On each sampling time, three packs of fish from each lot were taken from each treatment and storage temperature. Analysis of microbiological and chemical parameters was terminated on the days sensory spoilage was observed (attributes such as flesh color and off-odor) for packages stored at $8{ }^{\circ} \mathrm{C}$ and under passive-MA.
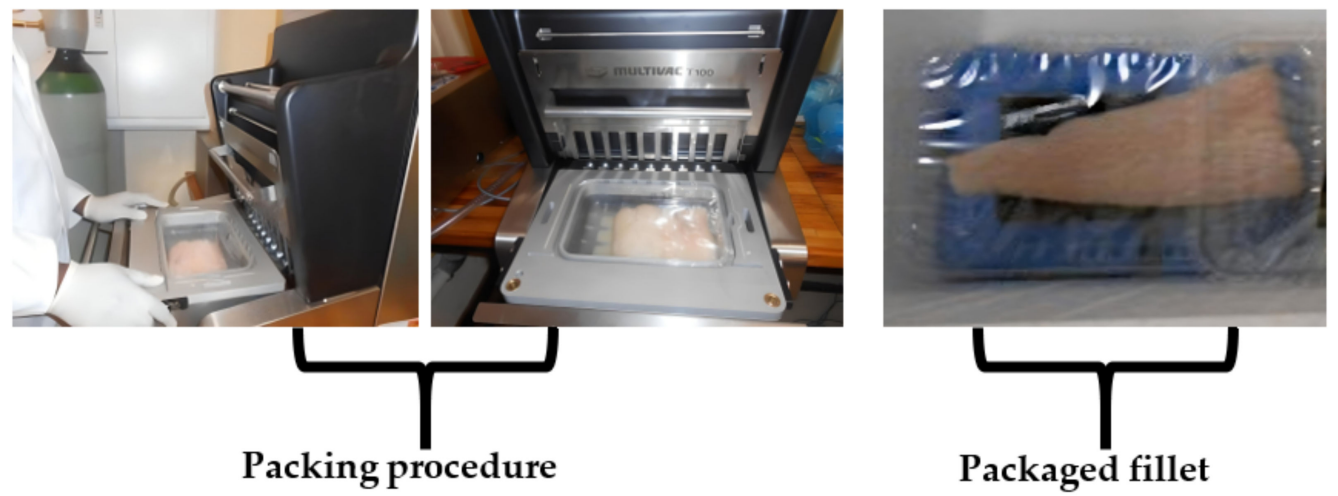

Figure 1. An illustration of the fish fillet packaging approach.

\subsection{Headspace Gas Analysis and Temperature}

Before the packages were opened, changes in $\mathrm{CO}_{2}$ and $\mathrm{O}_{2}$ levels in the headspace of the tray were measured using a gas analyzer with $0.5 \%$ accuracy (Checkmate 3, PBI Dansensor, Ringstead, Denmark) and reported as a percentage (\%) of the atmosphere composition inside the package. Three packages were measured for each treatment at sampling day. After the gas composition analyses, packs were unwrapped for further analysis of fillet quality attributes.

\subsection{Physicochemical Analysis}

\subsection{1. $\mathrm{pH}$}

Fish samples from each package treatment were homogenized in milliQ water (Millipak ${ }^{\circledR}$ express 40 filter unit, Merck KGaA, Darmstadt, Germany) and dilution was used to measure the $\mathrm{pH}$ using a Crison $\mathrm{pH}$ meter Basic 20+ (Crison, Barcelona, Spain). The $\mathrm{pH}$ meter was standardized using buffer solutions of $\mathrm{pH} 9.02 \pm 0.01,7.00 \pm 0.01$, and $4.01 \pm 0.01$ at $25^{\circ} \mathrm{C}$ as described by Erkan et al. [21].

\subsubsection{Color}

Color attributes of fillets were measured with a colorimeter (Chroma Meter CR-400, Minolta corp., Osaka, Japan). To make representative measurements, approximately five measurements were taken on each fillet. The CIELAB parameters were assessed: $L^{*}$ (describing lightness/brightness), $a^{*}$ (describing the balance of green to red), and $b^{*}$ (describing blue to yellow). Total color difference $(\Delta E)$ was calculated based on the magnitude of color difference between the baseline sample and other sampling days using Equation (1):

$$
\Delta E=\sqrt{\left(a-a_{o}^{*}\right)^{2}}+\left(b-b_{o}^{*}\right)^{2}+\left(L-L_{o}^{*}\right)^{2}
$$

where $a_{0}{ }^{*}, b_{0}{ }^{*}$, and $L_{0}{ }^{*}$ are the baseline values for unpackaged fresh Cape hake fillets at day 0 , and $a^{*}, b^{*}$, and $L^{*}$ are the values for fillets packaged under each treatment at each sampling day [35]. 


\subsubsection{Firmness Measurement}

The firmness of each fillet was determined by using a texture profile analyzer fitted with the Warner Bratzler Blade-set (HDP/BS; TA-XT Plus, Stable Micro Systems, Surrey, England). A test speed of $1.5 \mathrm{~mm} \mathrm{~s}^{-1}$ and distance of $30 \mathrm{~mm}$ was used for the study. Firmness was expressed as the work of shear $(\mathrm{N} / \mathrm{s})$ based on the force required to shear through the fish muscle and connective tissues [36-38].

\subsubsection{Drip Loss}

Fish samples were carefully removed from the tray, leaving behind the drip. The tray containing the drip was then weighed to obtain the weight of the drip loss. Individual package trays were weighed prior to packaging. Thus, drip loss was calculated based on the difference between the gross weight of the package with drip and the known weight of the tray, and expressed as a percentage loss based on the initial sample weight as shown in Equation (2):

$$
\% D L=\frac{W_{i}-W_{s}}{W_{i}} \times 100
$$

where $D L$ is the drip loss (\%), $W_{i}$ is the gross weight of package and drip (g), and $W_{S}$ is the known weight of tray $(\mathrm{g})$. A conversion factor of $1 \mathrm{~g}=1 \mathrm{~mL}$ was used to covert $D L$ in weight $(\mathrm{g})$ to volume $(\mathrm{mL})$ [39].

\subsection{Microbial Quality Analysis}

Approximately $1 \mathrm{~g}$ of fish samples was taken from randomly selected packaged fillets for each treatment on the sampling day and mashed under aseptic conditions using mortar and pestle. Mashed samples were then diluted in test tubes containing $10 \mathrm{~mL}$ of sterile physiological saline solution (PSS; $0.85 \mathrm{~g} \mathrm{NaCl}$ in $100 \mathrm{~mL}$ distilled water). Serial dilutions up to four-folds were prepared by adding $1 \mathrm{~mL}$ of the homogenate sample to $9 \mathrm{~mL}$ PSS and the vortex of each dilution. To count the microbial load, $1 \mathrm{~mL}$ of each dilution was plated onto appropriate media in triplicates using the pour plate method. [40].

Aerobic mesophillic bacteria were counted using plate count agar (PCA) method 4833 [41]. The plates were incubated upside-down at $37^{\circ} \mathrm{C}$ for $48 \mathrm{~h}$ [42]. For the screening of Escherichia coli, violet-red bile glucose (VRBG) agar was used and plates were incubated upside-down at $37^{\circ} \mathrm{C}$ for $24 \mathrm{~h}$ [43]. Presence of Vibrio parahaemolyticus in fish fillet was investigated using a combination of the thio-sulphate bile salt sucrose agar (TCBS) and HiChrome vibrio agar method 21872-1 [44]. HiChrome vibrio Agar was used because color development by Vibrio species is not affected by the presence of colonies of other bacteria as the amount of color developed depends on the reaction of bacterial $\beta$-galactosidase with the substrate contained in the media. The plates were then incubated upside-down at $37^{\circ} \mathrm{C}$ for $24 \mathrm{~h}$ [32]. After incubation, plates with 30-300 colonies were counted. The results were transformed into a Log colony-forming unit $\left(\log \mathrm{CFU} \mathrm{g}{ }^{-1}\right)$.

\subsection{Proximate Analysis}

Proximate analysis was carried out only on day 0 and at the end of 12 and 15 days of refrigerated storage. Crude protein analysis was carried out using a modification of Association of Official Analytical Collaboration (AOAC) method 981.10 and AOAC 960.52 micro-kjeldahl methods [45]. Approximately $2 \mathrm{~g}$ of fish sample was digested with $\mathrm{H}_{2} \mathrm{SO}_{4}$ using the heating digestion unit (DKL Automatic Digester, VELP Scientifica Srl, Usmate Velate $\mathrm{MB}$, Italy). The digested sample was then distilled with distillation unit (UDK 129, VELP Scientifica Srl, Usmate Velate MB, Italy) using $\mathrm{NaOH}$, Boric acid, and 5 drops of Bromo-cresol green indicator after cooling. The distillate was then titrated with $0.2 \mathrm{M} \mathrm{HCl}$ until the end point was reached, i.e., when the color changed from green to pink. The titer volume of acid used in the titration was documented. A blank was set without Cape hake fillets as the control. The percentage of protein content was calculated according to Equation (3): 


$$
\% \text { Nitrogen }=\text { Normality of } H C L \times \frac{\text { corrected acid vol. }(m l) n x}{g \text { of sample }} \times \frac{14 g N}{m o l} \times 100
$$

Percentage protein was calculated by multiplying the percentage of nitrogen with a conversion factor of 6.25 . The unit of normality is mol $/ 100 \mathrm{~mL}$. Corrected acid volume $=(\mathrm{mL}$ standard acid for sample) - (mL standard for blank).

Fat content was analyzed using the AOAC method [46]. The solvent extraction unit (SER 148, VELP Scientifica Srl, Usmate Velate MB, Italy) was used for fat extraction. About $3 \mathrm{~g}$ of the sample was extracted with the solvent extraction unit using petroleum ether (B.P. $60^{\circ} \mathrm{C}$ ) as the extracting solvent.

The moisture content of fish fillets was measured using AOAC Official Method 934.01 [47]. Clean, empty porcelain crucibles were dried for $2 \mathrm{~h}$ at $100^{\circ} \mathrm{C}$. The crucibles were then allowed to cool in desiccators for $30 \mathrm{~min}$ to $2 \mathrm{~h}$. Approximately $2.5 \mathrm{~g}$ of the sample was weighed into the dried crucibles and heated to $105^{\circ} \mathrm{C}$ for $24 \mathrm{~h}$ in a Pro-Lab oven and incubator (OTE 160L Lab tech. Separation Scientific, South Africa). The crucibles were allowed to cool down for $30 \mathrm{~min}$ and then weighed. This was then expressed as a percentage of the sample weight [47]. Ash content was then determined by continuing with dried samples obtained from the moisture loss analysis and the samples were ashed using Muffle Furnace (LEF 115 P-1 Lab Tech. Separation Scientific, Roodepoort, South Africa). Crucibles containing moisture-free fish samples were placed in the furnace and incubated at $500^{\circ} \mathrm{C}$ for $6 \mathrm{~h}$. The crucibles were placed in a desiccator and allowed to cool overnight. The crucibles were then weighed accurately and expressed as a percentage of the sample weight [48].

\subsection{Sensory Analysis}

Consumer sensory analyses were based on a hedonic scale using untrained sensory panels [49]. The panel consisted of 10 untrained researchers who were familiar with fresh fish. The preferences and evaluation of the quality of Cape hake were determined immediately after opening the containers with chilled fish. The appearance, odor, and overall acceptability of the Cape fillets were scored on five-point hedonic scale: 1 = dislike a lot and $5=$ like a lot. The average score for each parameter was calculated and presented as the sensory scores' appearance, odor, and overall acceptability.

\subsection{Statistical Analysis}

Statistical analysis was carried out using Statistica software (Statistica version 11, StatSoft Inc., Tulsa, OK, USA). Factorial analysis of variance (ANOVA) at the 95\% confidence interval was used to evaluate the combined effect of modified atmosphere packaging (MAP), storage temperature, and absorbent pads on the quality of packaged Cape hake fillets. When there was a statistical significance of the main factors and the interaction between them, the Fischer LSD multiple-range post-hoc tests were used to determine the significant differences. To establish correlation trends between physicochemical, microbial, and sensory qualities of the examined Cape hake fillets, data were processed according to principal component analysis (PCA) using XLSTAT software Version 2012.4.01 (Addinsoft, Paris, France). Significant correlation coefficients were classified as strong, moderate, and weak, corresponding to $\mathrm{r}>0.7, \mathrm{r}>0.5-<0.7$, and $\mathrm{r}<0.5$, respectively.

\section{Results and Discussion}

\subsection{Headspace Gas Composition}

Level of $\mathrm{O}_{2}$ decreased continuously across all treatments, with passive-MA packaged fillets reaching critical levels of $2.7 \%$ at the end of the storage life (Figure 2). In active-MA packaged fillets (Figure $2 \mathrm{a}, \mathrm{b}$ ), the levels of $\mathrm{O}_{2}$ decreased during storage; however, the levels did not reach critical limits and the lowest level was $9.5 \%$ at $0{ }^{\circ} \mathrm{C}$. Similar results were obtained for cod fillets packaged with gas composition $\left(37 \% \mathrm{CO}_{2}+63 \% \mathrm{O}_{2}\right)$ and stored at $0{ }^{\circ} \mathrm{C}$ for 14 days [22]. The author reported that this decrease was associated with utilization of $\mathrm{O}_{2}$ by microbes and biochemical interactions such as the oxidation of lipids in the fillets packed [22]. High levels of $\mathrm{O}_{2}$ assisted in inhibiting the development of 
anaerobic environments and preventing the occurrence of pathogenic anaerobes, such as non-proteolytic Clostridium botulinum [50].
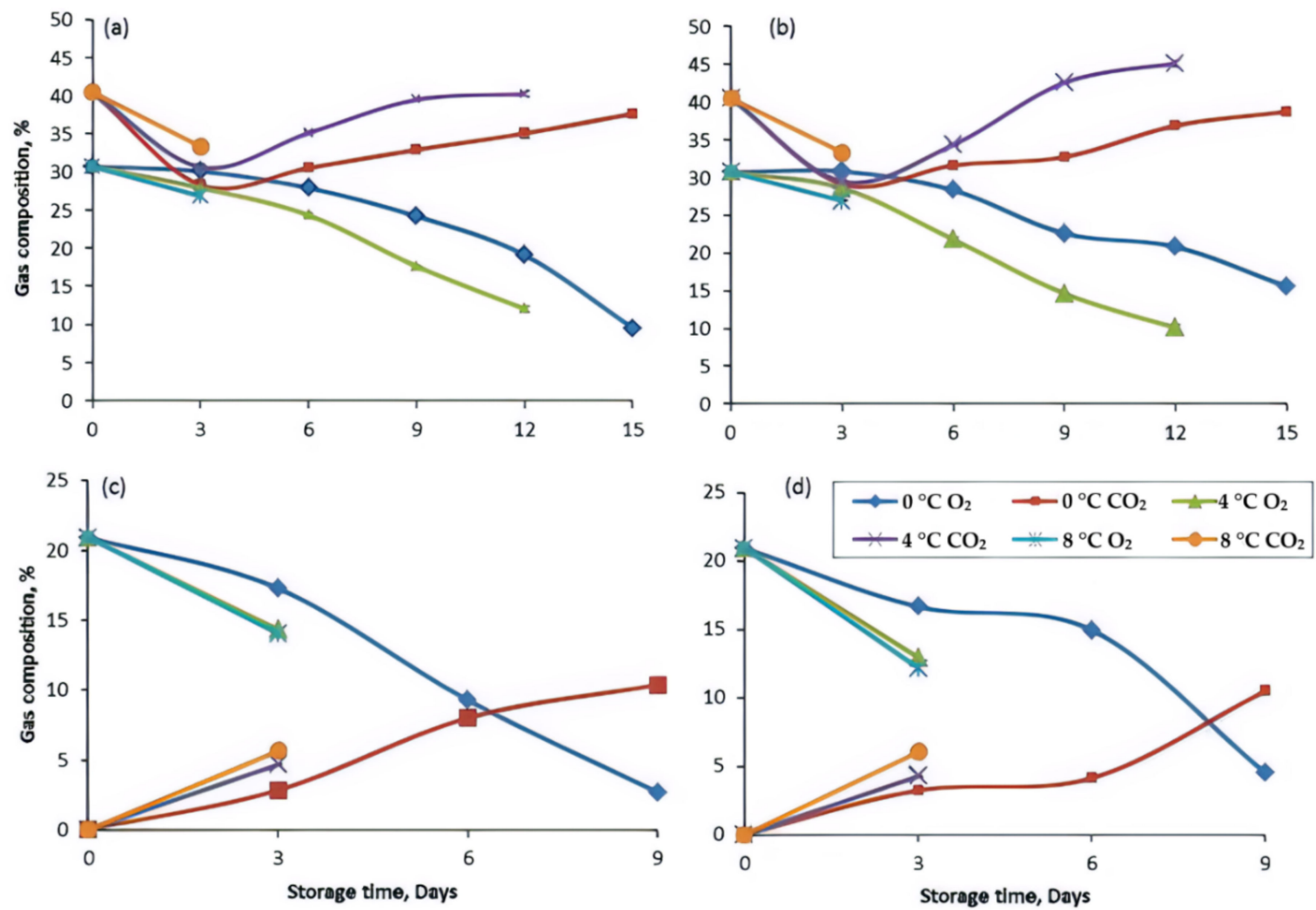

Figure 2. Effects of absorbent pads, packaging, temperature $\left(0^{\circ} \mathrm{C}, 4^{\circ} \mathrm{C}\right.$, and $\left.8^{\circ} \mathrm{C}\right)$, and time on oxygen and carbon dioxide gas composition during storage: (a) MAP with no PAD, (b) MAP plus PAD, (c) PMAP with no PAD, and (d) PMAP plus PAD. MAP = active-MAP and PMAP = passive-MAP.

Furthermore, an initial decrease in $\mathrm{CO}_{2}$ levels was observed for fillets stored under active-MAP across all temperatures. The decrease was higher at $0{ }^{\circ} \mathrm{C}$ compared with $4{ }^{\circ} \mathrm{C}$ and $8{ }^{\circ} \mathrm{C}$ on day 3 (Figure 2a,b). After day 3 , there was a subsequent increase in $\mathrm{CO}_{2}$ levels and the highest increase was observed at $4{ }^{\circ} \mathrm{C}$ on day 12 with a value of $40.2 \%$ (Figure 2a,b). The increase in $\mathrm{CO}_{2}$ may be ascribed to the increase in the metabolic activity of the spoilage bacteria [51-53]. The initial drop in $\mathrm{CO}_{2}$ levels during first days of storage for MA-stored fillets could be attributed to the dissolution of $\mathrm{CO}_{2}$ in muscle fluids of Cape hake fillets [51-53]. This trend confirms that $\mathrm{CO}_{2}$ becomes more soluble in water at lower temperatures [54]. Similar results were reported by Cyprian et al. [55] in their study on Nile tilapia packaged in $50 \% \mathrm{CO}_{2}+50 \% \mathrm{~N}_{2}$ and $100 \%$ air, and stored at $-1{ }^{\circ} \mathrm{C}$ and $1{ }^{\circ} \mathrm{C}$ for 27 and 20 days, respectively. The authors stated that $\mathrm{CO}_{2}$ levels dropped initially during storage until day 3, although it stabilized later with fillets packed under MA [55]. Similarly, $\mathrm{CO}_{2}$ levels in fresh cod loins packaged with gas composition $\left(50 \% \mathrm{CO}_{2}+5 \% \mathrm{O}_{2}+45 \% \mathrm{~N}_{2}\right)$ and stored at $1.5^{\circ} \mathrm{C}$ and $-0.9^{\circ} \mathrm{C}$ for 21 days decreased rapidly in the first few days of storage and then later increased [56]. The rate of decrease was higher at lower temperatures [56].

\subsection{Proximate Composition}

There were no significant changes in the proximate composition of active-MA packaged fillets at $0{ }^{\circ} \mathrm{C}$ after 15 days in storage in comparison to day 0 . In contrast, proximate composition of fillets stored under passive-MAP decreased due to the deterioration in fish flesh (results not shown). Fat, protein, moisture, and ash content values ranged from 0.29 to $0.286 \%$, 17.22 to $17.21 \%, 82.95$ to $82.88 \%$, and 4.90 to $4.80 \%$, respectively, for active-MAP stored fillets after storage. This agrees with findings reported by Del Nobile et al. [3] for blue fish burger consisting of fresh hake and mackerel fillets stored under three different gas compositions of 
$40 \% \mathrm{CO}_{2}+30 \% \mathrm{O}_{2}+30 \% \mathrm{~N}_{2}, 50 \% \mathrm{CO}_{2}+50 \% \mathrm{O}_{2}$, and $5 \% \mathrm{O}_{2}+95 \% \mathrm{CO}_{2}$ for 28 days at $4{ }^{\circ} \mathrm{C}$. The authors observed that the different gas compositions had no significant effect on the fat, moisture, and protein content of hake and mackerel fillets. Results obtained were also in agreement with findings on chub mackerel fish packaged with $50 \% \mathrm{CO}_{2}+50 \% \mathrm{~N}_{2}$ and stored at $3{ }^{\circ} \mathrm{C}$ and $6{ }^{\circ} \mathrm{C}$ for 15 days. In the study by Stamatis and Arkoudelos [57], MA did not influence the proximate composition.

Nevertheless, the proximate composition obtained in this study differed from those reported for hake fish from the Galician Sea, Spain, stored at $-10{ }^{\circ} \mathrm{C}$ and $-30{ }^{\circ} \mathrm{C}$ for 40 weeks. The values obtained were moisture $(80.2 \%)$, ash $(1.17 \%)$, total protein $(18.7 \%)$, and fat $(0.9 \%)$ [58]. The difference in the proximate composition may be related to the fact that the chemical composition of marine fish is dependent on the catching period, fish diet, habitat, fish size, deviations due to season and gender, and other environmental conditions [59].

\subsection{Physicochemical Analysis \\ 3.3.1. $\mathrm{pH}$}

Average $\mathrm{pH}$ at the end of storage was 6.3 and 7.1 for active-MAP and passive-MAP, respectively (Figure 3 and Table 1). A significant increase in $\mathrm{pH}$ was observed for all treatments during the storage period $(p<0.05)$. Temperature, packaging, and duration had a significant impact on the $\mathrm{pH}$ of fillets (Table 1). Lower values of $\mathrm{pH}$ were observed in active-MA packaged fillets stored at $0{ }^{\circ} \mathrm{C}(6.18)$ in comparison to $4{ }^{\circ} \mathrm{C}$ (6.43; Table 1$)$. However, $\mathrm{pH}$ was higher in active-MA packs without PAD than those with PAD and this was consistent for all temperature conditions (Table 1). The $\mathrm{pH}$ values of fillets stored at $0{ }^{\circ} \mathrm{C}$ on day 15 for active-MA packages without PAD was 6.23 and with PAD was 6.13 (Table 1). In contrast, passive-MA packaged fillets had $\mathrm{pH}$ values of 7.96 and 7.94 for no PAD and plus PAD fillets, respectively, on day 9 at $0{ }^{\circ} \mathrm{C}$ (Table 1 ). In addition, the fillets stored under active-MAP exhibited an initial slow increase in $\mathrm{pH}$ at the start of the storage period. This was due to dissolved $\mathrm{CO}_{2}$ in the liquid phase of the muscle tissue giving rise to non-dissociated carbonic acid as observed by other researchers $[20,22,25]$.

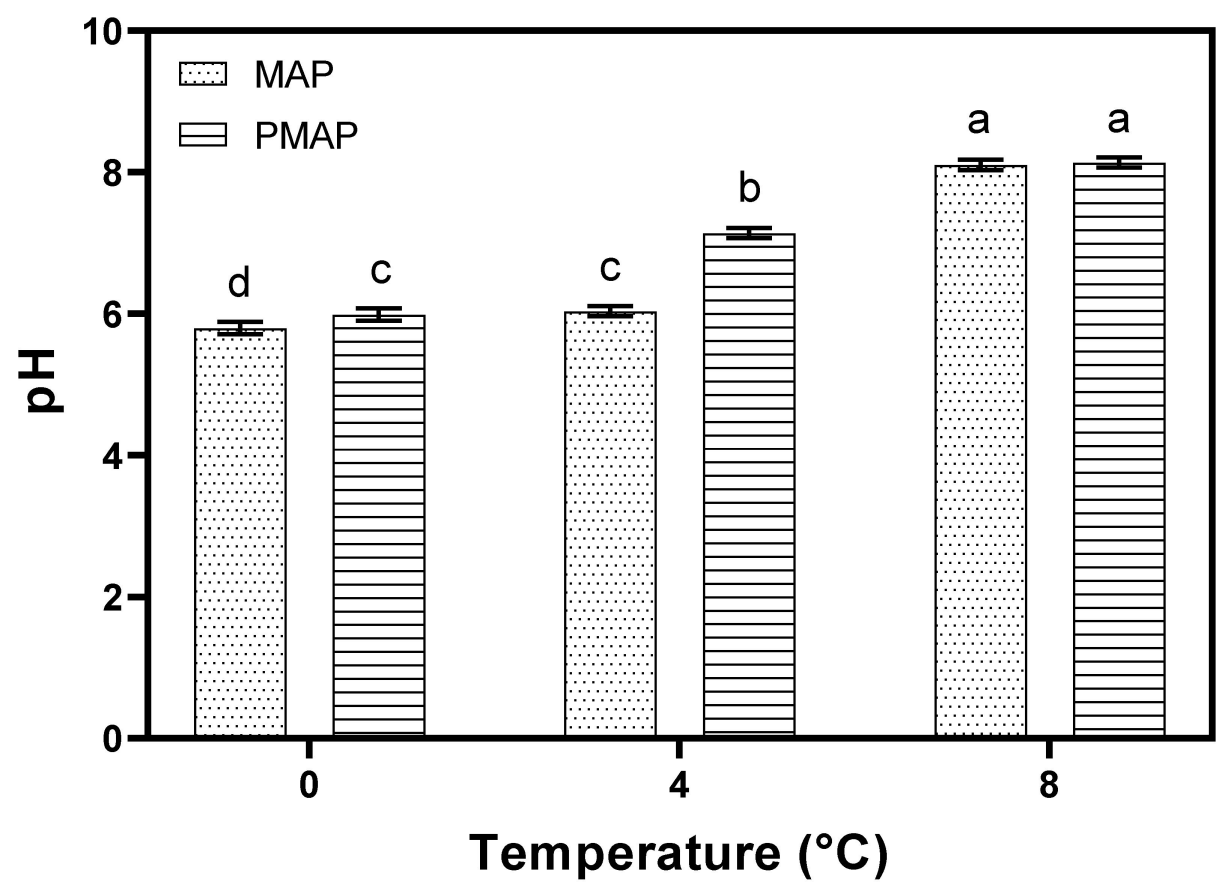

Figure 3. Effects of active and passive modified atmosphere packaging and storage temperatures $\left(0{ }^{\circ} \mathrm{C}, 4^{\circ} \mathrm{C}\right.$, and $\left.8{ }^{\circ} \mathrm{C}\right)$ on the change in $\mathrm{pH}$ on day 3 . Different letters represent mean values that are significantly different $(p<0.0001)$ MAP $=$ active-MA and PMAP $=$ passive-MA. 
Table 1. Effects of storage temperatures $\left(0^{\circ} \mathrm{C}, 4^{\circ} \mathrm{C}\right.$, and $\left.8^{\circ} \mathrm{C}\right)$, duration $(\mathrm{d})$, and modified atmosphere packaging with/without absorbent pads on $\mathrm{pH}$ of Cape hake fillets.

\begin{tabular}{|c|c|c|c|c|c|}
\hline Storage Days & TEMP. $\left({ }^{\circ} \mathrm{C}\right)$ & MAP - PAD & MAP + PAD & PMAP - PAD & PMAP + PAD \\
\hline 0 & - & $5.7 \pm 0.013^{n}$ & $5.7 \pm 0.013^{n}$ & $5.7 \pm 0.013^{n}$ & $5.7 \pm 0.013^{n}$ \\
\hline \multirow{3}{*}{3} & 0 & $5.8 \pm 0.004^{\mathrm{m}}$ & $5.7 \pm 0.006^{\mathrm{n}}$ & $6.1 \pm 0.004^{j}$ & $5.9 \pm 0.004^{1}$ \\
\hline & 4 & $6.1 \pm 0.009 \mathrm{j}$ & $5.9 \pm 0.006^{1}$ & $7.2 \pm 0.006^{\mathrm{e}}$ & $7.1 \pm 0.003^{\mathrm{f}}$ \\
\hline & 8 & $7.4 \pm 0.004^{\mathrm{d}}$ & $7.1 \pm 0.005^{\mathrm{f}}$ & $8.2 \pm 0.005^{\mathrm{a}}$ & $8.1 \pm 0.004^{b}$ \\
\hline \multirow{2}{*}{6} & 0 & $6.0 \pm 0.006^{\mathrm{k}}$ & $6.0 \pm 0.006^{k}$ & $7.9 \pm 0.013^{c}$ & $7.9 \pm 0.013^{c}$ \\
\hline & 4 & $6.4 \pm 0.006^{g}$ & $6.3 \pm 0.006^{h}$ & nd & nd \\
\hline \multirow{2}{*}{9} & 0 & $6.2 \pm 0.010^{1}$ & $6.1 \pm 0.003^{j}$ & nd & nd \\
\hline & 4 & $6.4 \pm 0.012^{g}$ & $6.3 \pm 0.005^{h}$ & nd & nd \\
\hline \multirow{2}{*}{12} & 0 & $6.2 \pm 0.004^{\mathrm{i}}$ & $6.1 \pm 0.004 \mathrm{j}$ & nd & nd \\
\hline & 4 & $6.4 \pm 0.005^{g}$ & $6.3 \pm 0.006^{h}$ & nd & nd \\
\hline \multirow[t]{2}{*}{15} & 0 & $6.2 \pm 0.004^{i}$ & $6.1 \pm 0.004^{j}$ & nd & nd \\
\hline & $\begin{array}{l}\text { nd }=\text { nc } \\
\text { letters i } \\
\text { pad; M } \\
\text { PMAP + } \\
\text { critical b } \\
\text { similarl } \\
\text { samplin }\end{array}$ & $\begin{array}{l}\text { nined due to sen } \\
\text { a significant diffe } \\
\text { D: active-MA wit } \\
\text { assive-MA with } \\
\text { counts were reach } \\
\text { ing for fillets store } \\
\text { ets stored under } P\end{array}$ & $\begin{array}{l}\text { jection. All valu } \\
\text { pH values }(p< \\
\text { bent pad; PMA } \\
\text { nt pad. Samplin } \\
\text { s sampling for fi } \\
\text { r PMAP at } 4{ }^{\circ} \mathrm{C} \\
t 0^{\circ} \mathrm{C} \text { was stoppe }\end{array}$ & $\begin{array}{l}\text { nded off to one } s \\
\text { MAP - PAD = act } \\
\text { AD: passive-MA } \\
\text { stopped on days } \\
\text { red under MAP at } \\
\text { were stopped on } \\
\text { ay } 6 \text {. }\end{array}$ & $\begin{array}{l}\text { ant figure. Diffe } \\
\text { A without absorb } \\
\text { absorbent pad; } \\
\text { sensory spoilage } \\
\text { vas stopped on da } \\
\text { as well. Addition }\end{array}$ \\
\hline
\end{tabular}

There was a subsequent increase in $\mathrm{pH}$ as storage progressed in fillets stored at $0{ }^{\circ} \mathrm{C}$ and $4{ }^{\circ} \mathrm{C}$ under active-MAP. At the end of the storage, $\mathrm{pH}$ was higher in fillets packed under passive-MA than active-MA. These results corroborate the report on active-MA packaged ready-to-eat hake, chub mackerel, yellow gurnard, and cuttle fillets stored at $4{ }^{\circ} \mathrm{C}$ for 14 days. Lower $\mathrm{pH}$ was observed under active-MA in comparison to passiveMA [19]. Thus, based on the role of $\mathrm{pH}$ in limiting microbial growth, gas composition of $40 \% \mathrm{CO}_{2}+30 \% \mathrm{O}_{2}+30 \% \mathrm{~N}_{2}$ at $0{ }^{\circ} \mathrm{C}$ is ideal in storing Cape hake fillets due to the observed lowest differences of $\mathrm{pH}$ during the trials.

\subsubsection{Drip Loss}

Drip loss increased significantly with storage time for Cape hake fillets stored under active-MA as well as for those under passive-MA without the absorbent pad. Absorbent pads were effective in preventing the accumulation of drips in other treatments (Figure 4). Furthermore, the interaction of storage temperature, duration, and absorbent pads had a significant influence on the drip loss in fillets packaged under active-MA (Figure 4). Generally, it was observed that drip loss was highest at the lowest temperature. This might be due to the increased solubility of $\mathrm{CO}_{2}$ at lower temperatures, resulting in lower $\mathrm{pH}$, which leads to a loss of the water-holding capacity in fish tissue and release of drips [20,22].

Similar results were obtained by Fletcher et al. [60] who studied the impact of two different gas mixtures $\left(100 \% \mathrm{CO}_{2}\right.$ and $\left.40 \% \mathrm{CO}_{2}+60 \% \mathrm{~N}_{2}\right)$ on the quality of fresh King salmon stored at $0{ }^{\circ} \mathrm{C}$ for 90 days. The authors stated that drip loss increased with storage time and higher drip loss was reported in the $100 \% \mathrm{CO}_{2}$ packages [60]. This was also corroborated by an investigation on the effect of MAP $\left(37 \% \mathrm{CO}_{2}+63 \% \mathrm{O}_{2}\right)$ on cod fillets stored at $0{ }^{\circ} \mathrm{C}$ for 14 days. Presence of $\mathrm{CO}_{2}$ in the MA packaged cod fillets resulted in the formation of drips and the higher the levels of $\mathrm{CO}_{2}$ in a package, the higher the drips [22] Studies have shown that dissolved $\mathrm{CO}_{2}$ in fish tissues leads to reduced $\mathrm{pH}$ in $\mathrm{MA}$ packaged fillets. This initiates drip loss, which might be due to tissue pliability and loss of the fluid-retaining ability $[50,61,62]$. The presence of drip loss in packaged fillets reduces the freshness quality. Therefore, the use of absorbent pads assists in improving fillet quality. 


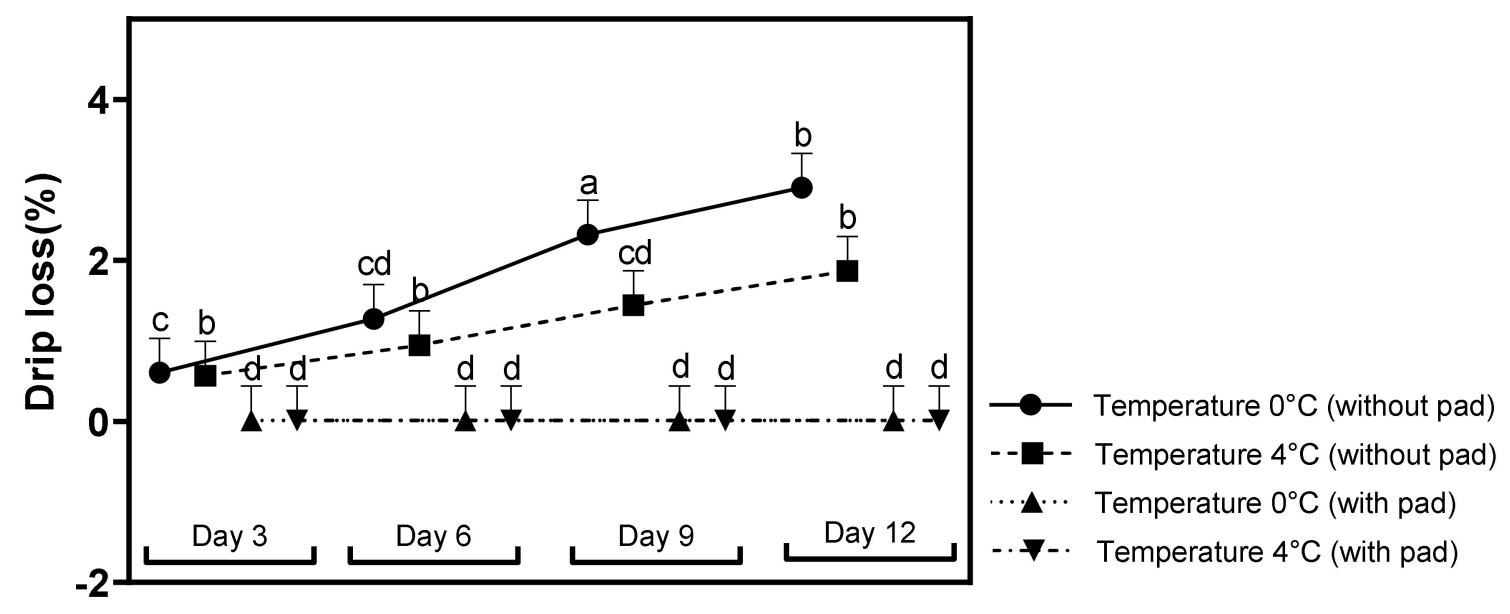

Figure 4. Effect of the interaction of storage temperature, with or without absorbent pads, and storage duration (d) on drip loss for active-MA packaged fillets; different letters indicate a significant difference $(p<0.001)$.

\subsubsection{Fillet Firmness}

Firmness of fresh Cape hake fillets at day 0 based on the measurement of the work of shear was $838.9 \pm 34.1 \mathrm{~N} / \mathrm{s}$ and this decreased over time during storage across all treatments. Fillets stored under active-MAP maintained better firmness than those under passive-MAP across all treatments. The interaction of the modified atmosphere gas composition (in packages) and storage temperature had a significant effect $(p<0.001)$ on the firmness of the hake fillets (Figure 5 and Table S1). Passive-MA packaged fillets stored at $8^{\circ} \mathrm{C}$ had the lowest firmness values of $512.7 \pm 0.7 \mathrm{~N} / \mathrm{s}$ by day 3 . As storage time progressed, the firmness of hake fillets reduced but the firmness at lower temperatures was better across all treatments. This agrees with studies by Roth et al. [63] in which higher temperatures and time causes stored fish fillets to lose their firmness. This is because the degradation of fish muscles was better delayed under active-MAP at lower temperatures than under passive-MAP at $0{ }^{\circ} \mathrm{C}, 4{ }^{\circ} \mathrm{C}$, and $8{ }^{\circ} \mathrm{C}$. A similar effect was observed for Atlantic salmon stored at $-3.6{ }^{\circ} \mathrm{C}$ and $-1.4^{\circ} \mathrm{C}$ for 34 days. Firmness decreased with storage duration and lower temperature better helped to maintain firmness in stored salmon fillets [64].

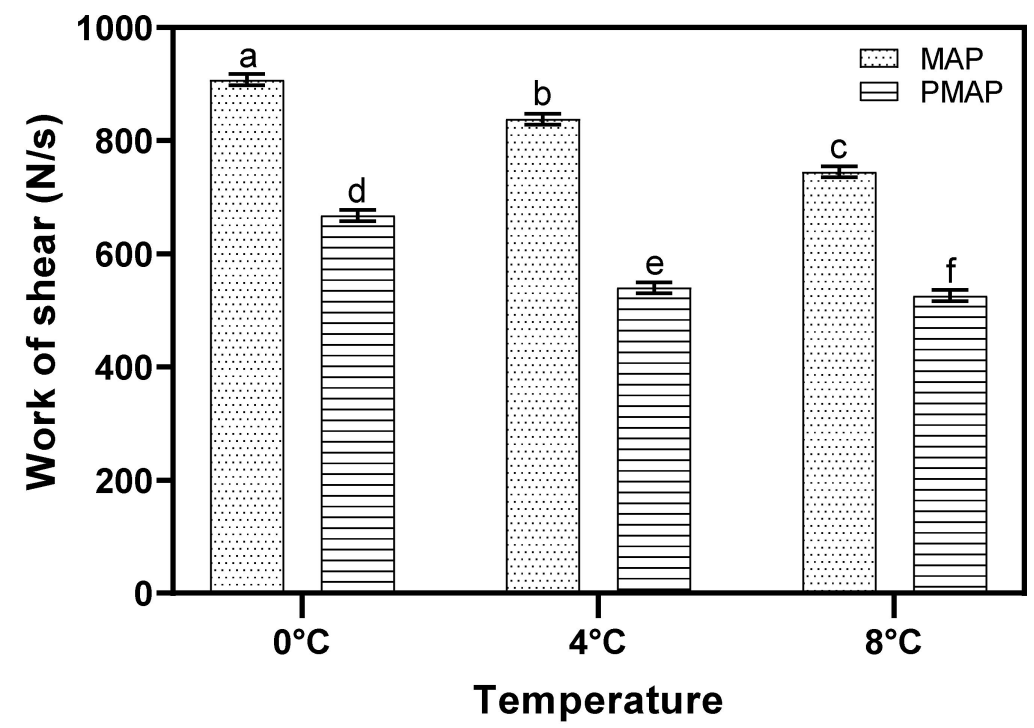

Figure 5. Effect of temperature and packaging on firmness (work of shear $(\mathrm{N} / \mathrm{s})$ ) on day 3 with absorbent pads. Different letters indicate a significant difference in work of shear values $(p<0.001)$. MAP $=$ active-MAP and PMAP $=$ passive-MAP. 
The use of absorbent pads had a significant impact on the firmness across all temperatures. Active-MAP with absorbent pads maintained better firmness at $0{ }^{\circ} \mathrm{C}$ than other temperature conditions during storage (Table S1). This could be attributed to the ability of the absorbent pad to better absorb drips in the pack and delay the degradation of fish muscles, which results in tissue pliability and hastens the loss of fish freshness [62]. Firmness is a vital attribute for fresh or ready-to-cook (RTC) fish but soft fillets are, however, a drawback in the marketing of fresh RTC fish [65]. Therefore, the use of absorbent pads offers a value addition to improve fillet quality.

\subsubsection{Color Measurement}

The total color difference (TCD) of fillets is presented in Figure 6 and Table S2. Temperature and duration led to significant increases in TCDs during the storage of fillets $(p<0.05)$. In addition, fillets stored under active-MAP had lower TCDs than those under passive-MAP (control), with fillets stored under active-MAP at $0{ }^{\circ} \mathrm{C}$ having the lowest TCD of 5.9 on day 12 (Figure 6). The change in fillets' TCD is consistent with results obtained for Atlantic salmon stored at $-1.4{ }^{\circ} \mathrm{C}$ and $3.6^{\circ} \mathrm{C}$ for 34 days [63]. The authors reported that temperature and duration are vital indices in determining color changes in Atlantic salmon fillets [63]. Similarly, Regost et al. [66] investigated the influence of essential oils and cold storage at $4{ }^{\circ} \mathrm{C}$ and $20{ }^{\circ} \mathrm{C}$ on muscle quality attributes of Atlantic salmon. The color of Atlantic salmon was shown to be dependent on both storage duration and temperature [66].

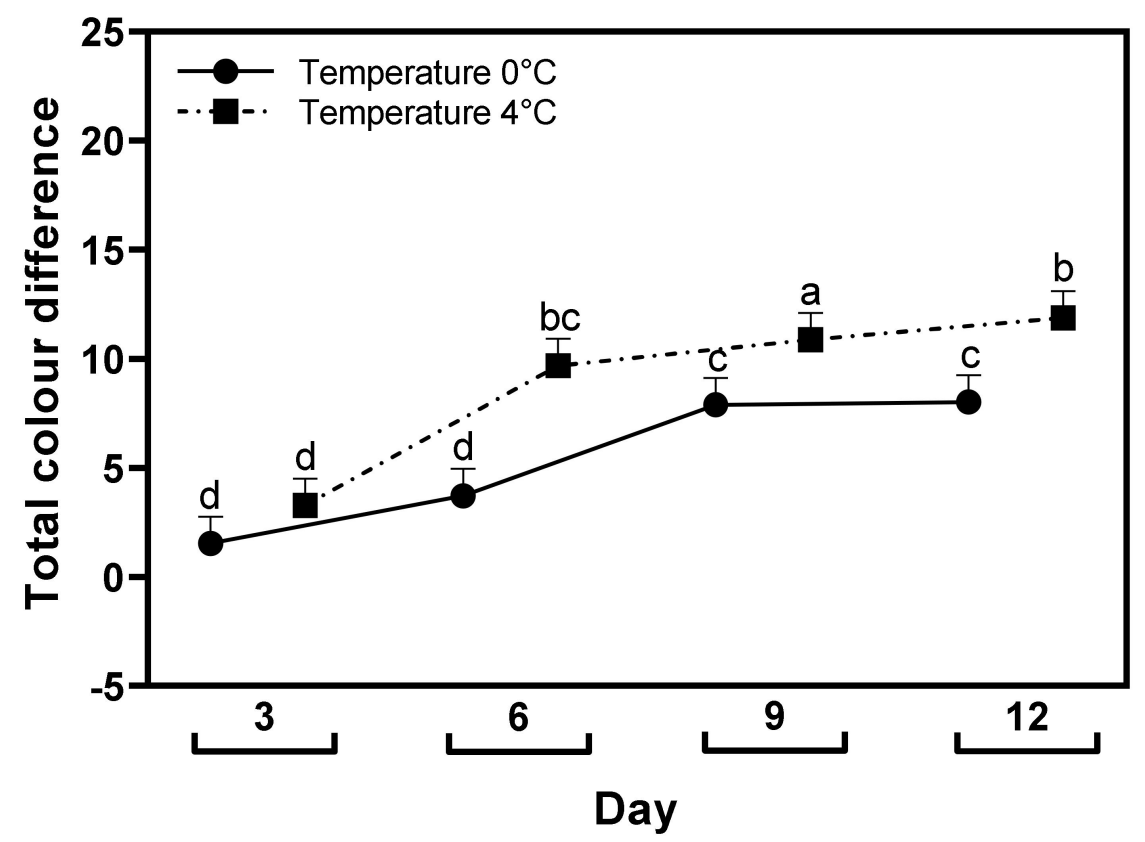

Figure 6. Effect of modified atmosphere packaging, temperature $\left(0{ }^{\circ} \mathrm{C}\right.$ and $\left.4{ }^{\circ} \mathrm{C}\right)$, and duration $(\mathrm{d})$ on total color difference of stored Cape hake fillets. Different letters indicate a significant difference in work of shear values $(p<0.02)$.

Oxidation of hemoglobin pigments is a major source of color change during the storage of fish fillets $[67,68]$. Chaijan et al. [69] reported on pigment and color differences in tissues of mackerel and sardine stored at $4{ }^{\circ} \mathrm{C}$ for 15 days. It was observed that levels of pigment and heme iron reduced, while non-heme iron levels improved through ice storage [69]. Thus, fish fillet color is best maintained at lower temperatures. This corroborated our results that lower temperature and active-MAP lowered the TCDs of fillets during storage.

\subsection{Microbiology Quality}

Fillets used in this study had initially good microbial quality, as evidenced by the low initial aerobic mesophillic bacteria (1.2 log cfu/g) and absence of both Vibrio spp and E. coli. The lowest aerobic mesophillic bacteria were observed in fillets stored under active-MAP 
while fillets stored at $0{ }^{\circ} \mathrm{C}$ had the least counts of $5.2 \log \mathrm{cfu} / \mathrm{g}$ on day 12 . The interaction of MAP, absorbent pads, and storage temperature had a significant effect on the aerobic mesophillic bacteria counts (Figure 7). In fillets stored at $4{ }^{\circ} \mathrm{C}$ and $8{ }^{\circ} \mathrm{C}$ under passive$\mathrm{MA}$, the aerobic mesophillic bacteria count reached the critical limits of $<5.5 \mathrm{log} \mathrm{cfu} / \mathrm{g}$ by day 3 [70], while fillets stored at $0{ }^{\circ} \mathrm{C}$ had lower counts. For fillets under active-MAP storage at $0{ }^{\circ} \mathrm{C}$ and $4{ }^{\circ} \mathrm{C}$, they did not exceed the critical limit until after day 12 and 9 , respectively (Table S3). These results agreed with the findings of Ordonez et al. [20] for MAP conditions ( $40 \% \mathrm{CO}_{2}+60 \%$ air, $20 \% \mathrm{CO}_{2}+80 \%$ air, and $100 \%$ passive-MAP) for hake fillets stored at $2{ }^{\circ} \mathrm{C}$ for 12 days. They reported that AMCs exceeded the microbial limits faster in fillets stored under $100 \%$ passive-MAP than active-MAP-stored fillets and MAP $\left(40 \% \mathrm{CO}_{2}+60 \%\right.$ air) was more efficient in hindering microbes [20]. This highlights the importance of maintaining the optimum cold chain for packaged fresh RTC fish products, as abusive handling temperature would result in a shorter shelf-life and compromise safety.
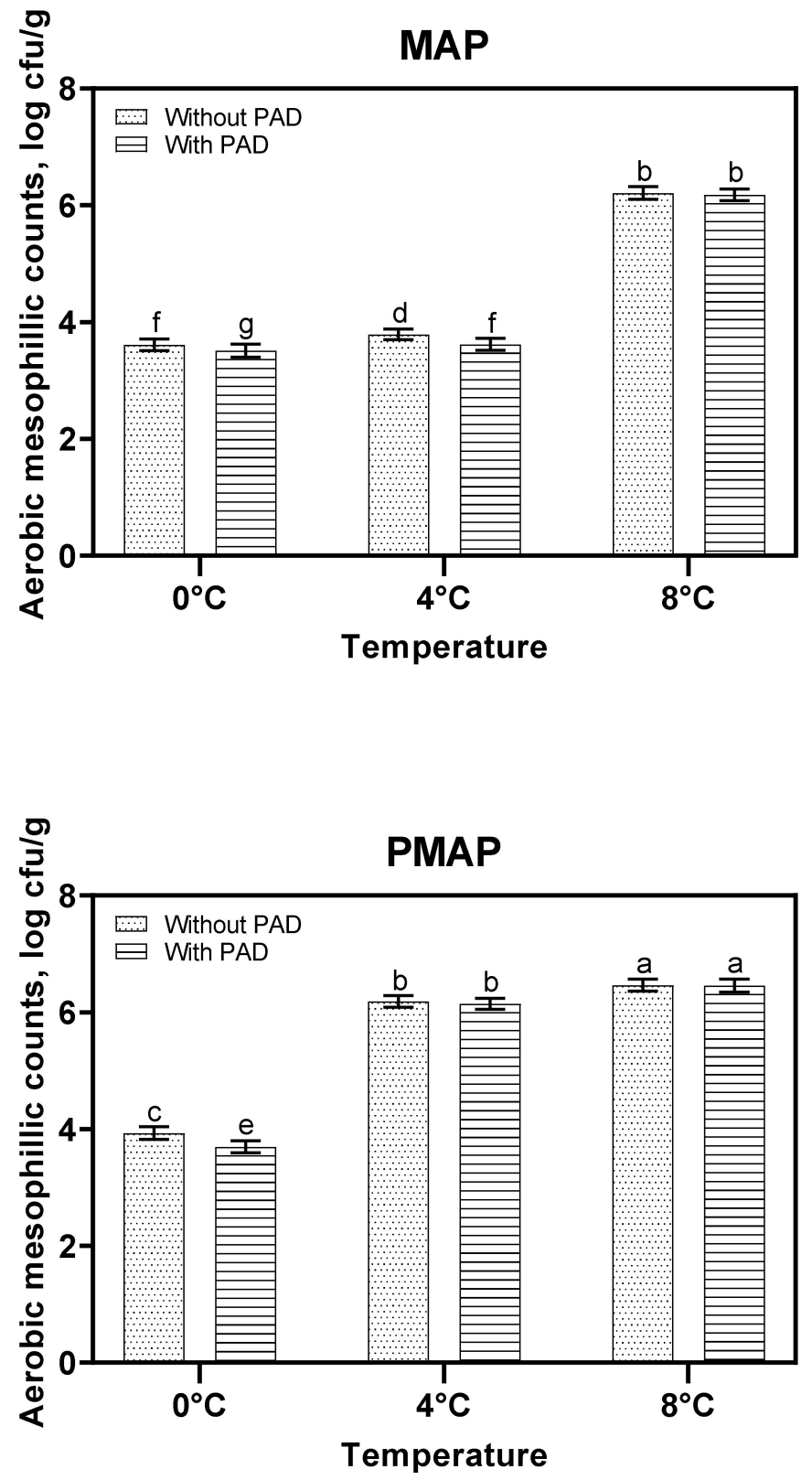

Figure 7. Effects of temperature $\left(0{ }^{\circ} \mathrm{C}, 4{ }^{\circ} \mathrm{C}\right.$, and $\left.8{ }^{\circ} \mathrm{C}\right)$ and packaging with/without absorbent pads on bacterial growth of fillets on day 3. Different letters indicate a significant difference in aerobic mesophillic count $(p<0.001)$. MAP = active-MA and PMAP = passive-MA. 
Furthermore, the use of pads led to lower microbial loads in fillets stored at $0{ }^{\circ} \mathrm{C}$ and $4{ }^{\circ} \mathrm{C}$ for active-MAP $(p<0.001)$ but the use of pads was only effective at $0{ }^{\circ} \mathrm{C}$ for fillets stored under passive-MAP (Figure 7 and Table S3). This could be attributed to the ability of the absorbent pad to better absorb drip loss in the package, which limits the exudates on which micro-organisms strive. Additionally, the lower microbial growth observed at $0{ }^{\circ} \mathrm{C}$ during storage might be due to the increased solubility of $\mathrm{CO}_{2}$ at lower temperatures, which increases acidity and inhibits microbial growth. This correlates with results obtained during $\mathrm{pH}$ analyses in this study which showed a slow increase in $\mathrm{pH}$ at $0{ }^{\circ} \mathrm{C}$ compared with $4{ }^{\circ} \mathrm{C}$. Similar results were reported by Ordonez et al. [20] for hake steaks as well as by Stamatis and Arkoudelos [57] for chub mackerel; they stated that aerobic mesophillic bacteria were better hindered when a slow increase in $\mathrm{pH}$ occurred $[20,57]$. Research findings have indicated that $\mathrm{CO}_{2}$ hinders the growth of psychotropic, aerobic, and Gram-negative microbes, and slows down the deterioration of fresh RTC fish fillets [57].

Previous studies have established that active-MAP lowers microbial loads by extending the lag phase of bacteria $[23,52,71]$. This effect was attributed to the dissolution of $\mathrm{CO}_{2}$, which leads to the formation of carbonic acid, the undissociated form of carbonic acid (bicarbonate ion) that changes cell permeability and hinders the metabolic processes of microbes [50]. Hence, the use of active-MAP combined with absorbent pads under optimum cold storage can assist in extending the shelf-life and maintain the microbial safety of RTC hake fillets.

In this study, E. coli and Vibrio spp. growths were not detected throughout the duration of storage and across all treatments. These microbes are indicators for spoilage and pathogenic microbes. This indicates that during this study, adequate hygiene levels were maintained and there was no cross-contamination from fecal material. Thus, for the success of any post-harvest treatments on fresh or minimally processed fish products, good agricultural practices (GAPs), hazard analysis, and critical control points (HACCP) along the processing and packaging stage should be strictly adhered to.

\subsection{Sensory Analysis}

Sensory scores for packaged Cape hake fillets are summarized in Table 2. Overall, the acceptability of fillets decreased with the increase in storage temperature across all treatments. Additionally, MA had a significant impact on the sensory attributes evaluated $(p<0.05)$, with active-MA packaged fillets stored at $0{ }^{\circ} \mathrm{C}$ having the highest scores for overall acceptability in comparison to fillets packaged under passive-MA. Temperature and time significantly influenced the appearance quality of fillets $(p<0.05)$. Like the findings from the measured fillet drip loss, sensory scores of drip loss (watery discharge) were higher in active-MA-packed fillets without pads than in passive-MA packages without pads $(p<0.05)$. The freshness scores decreased significantly as the temperature and storage time increased $(p<0.05)$. By day 12 , active-MA packaged fillets stored at $0{ }^{\circ} \mathrm{C}$ had higher freshness scores than fillets stored at $4{ }^{\circ} \mathrm{C}$.

The interaction of MA, storage temperature, and duration had significant effects on the overall acceptability of the fillets $(p<0.05)$. On day 6 of storage, the overall acceptability scores for passive-MA packaged fillets without pads were lower (2.1) than that of passive-MAP with absorbent pads (2.54) for fillets stored at $0{ }^{\circ} \mathrm{C}$. This low score observed correlates with the aerobic mesophillic counts, which were higher than the microbial limits of $<5.5 \log \mathrm{cfu} / \mathrm{g}$ by day 6 . Thus, based on sensory evaluation and microbial data, the shelflife of passive-MA packaged Cape hake fillets stored at $0{ }^{\circ} \mathrm{C}$ was limited to $<6$, while $4{ }^{\circ} \mathrm{C}$ and $8{ }^{\circ} \mathrm{C}$ were limited to $<3$ days. On the other hand, fillets under active-MAP with pads stored at $0{ }^{\circ} \mathrm{C}$ had a higher overall acceptability score (3.02) than those stored at $4{ }^{\circ} \mathrm{C}(1.76)$ on day 12 . The sensory score obtained for active-MA packaged fillets was consistent with the aerobic mesophillic counts reported on day 12. Aerobic mesophillic counts for activeMA packaged fillets stored at $4{ }^{\circ} \mathrm{C}$ exceeded the microbial limits of $5.5 \log \mathrm{cfu} / \mathrm{g}$ by day 9 , but those of $0{ }^{\circ} \mathrm{C}$ were within the microbial limits. Therefore, based on sensory attributes and the microbial load, the shelf-life of active-MA packaged Cape hake fillets stored at $4{ }^{\circ} \mathrm{C}$ 
was limited to about 9 days. The shelf-life reported for active-MA packaged Cape hake fillets stored at $4{ }^{\circ} \mathrm{C}$ in this study was shorter than the shelf-life of 10 days, as reported by Speranza et al. [19] for hake fillets stored at $4{ }^{\circ} \mathrm{C}$. This could be due to the difference in the fish habitat, season when fish were harvested, as well as the post-harvest treatment.

Table 2. Consumer perception scores of packaged Cape hake fillets during storage.

\begin{tabular}{|c|c|c|c|c|c|c|c|c|}
\hline \multirow{2}{*}{ Storage (Days) } & \multirow{2}{*}{ TEMP. $\left({ }^{\circ} \mathrm{C}\right)$} & Treatment & - & Appearance & - & Odor & - & - \\
\hline & & - & Color & Watery Discharge & Firmness & Fish Freshness & Not Fermenting & Overall Acceptability \\
\hline \multirow{12}{*}{3} & \multirow{4}{*}{0} & $\mathrm{MAP}-\mathrm{PAD}$ & $4.70 \pm 0.48 \mathrm{~b}$ & $2.50 \pm 0.53 \mathrm{~g}$ & $4.40 \pm 0.52 \mathrm{~b}$ & $480 \pm 0.42^{b}$ & $4.50 \pm 0.53 \mathrm{~b}$ & $4.18 \pm 0.05^{b}$ \\
\hline & & $\mathrm{MAP}+\mathrm{PAD}$ & $5.00 \pm 0.01^{\mathrm{a}}$ & $5.00 \pm 0.01 \mathrm{a}$ & $5.00 \pm 0.01 \mathrm{a}$ & $4.90 \pm 0.32 \mathrm{a}$ & $5.00 \pm 0.01 \mathrm{a}$ & $4.98 \pm 0.14 \mathrm{a}$ \\
\hline & & PMAP - PAD & $3.90 \pm 0.32 \mathrm{~d}$ & $4.10 \pm 0.32^{c}$ & $2.20 \pm 0.63 \mathrm{e}$ & $3.40 \pm 0.52 \mathrm{e}$ & $3.20 \pm 0.42 \mathrm{e}$ & $3.36 \pm 0.14^{\mathrm{d}}$ \\
\hline & & PMAP + PAD & $4.50 \pm 0.53^{c}$ & $4.80 \pm 0.42 \mathrm{~b}$ & $3.40 \pm 0.52^{c}$ & $4.30 \pm 0.48^{c}$ & $3.60 \pm 0.52^{c}$ & $4.12 \pm 0.04^{c}$ \\
\hline & \multirow{4}{*}{4} & $\mathrm{MAP}-\mathrm{PAD}$ & $2.60 \pm 0.70 \mathrm{f}$ & $1.70 \pm 0.48^{\mathrm{i}}$ & $2.50 \pm 0.53 \mathrm{~d}$ & $280 \pm 0.63^{d}$ & $3.00 \pm 0.47^{\mathrm{f}}$ & $2.52 \pm 0.10^{f}$ \\
\hline & & $\mathrm{MAP}+\mathrm{PAD}$ & $2.90 \pm 0.57 \mathrm{e}$ & $3.90 \pm 0.57 \mathrm{~d}$ & $2.50 \pm 0.53 \mathrm{~d}$ & $3.80 \pm 0.63 \mathrm{~d}$ & $3.50 \pm 0.53 \mathrm{~d}$ & $3.32 \pm 0.04 \mathrm{e}$ \\
\hline & & PMAP - PAD & $1.50 \pm 0.53 \mathrm{~h}$ & $2.50 \pm 0.85 \mathrm{~g}$ & $1.60 \pm 0.52 \mathrm{~h}$ & $2.70 \pm 0.48$ & $2.50 \pm 0.53 \mathrm{~h}$ & $2.16 \pm 0.15 \mathrm{~h}$ \\
\hline & & PMAP + PAD & $1.40 \pm 0.70^{\mathrm{i}}$ & $2.30 \pm 0.48 \mathrm{~h}$ & $2.00 \pm 0.67^{f}$ & $3.00 \pm 0.67^{f}$ & $2.80 \pm 0.42 \mathrm{~g}$ & $2.30 \pm 0.13 \mathrm{~g}$ \\
\hline & \multirow{4}{*}{8} & $\mathrm{MAP}-\mathrm{PAD}$ & $1.00 \pm 0.01 \mathrm{k}$ & $1.60 \pm 0.32^{j}$ & $1.50 \pm 0.71^{\mathrm{i}}$ & $1.20 \pm 0.42 \mathrm{~h}$ & $1.00 \pm 0.32 \mathrm{j}$ & $1.26 \pm 0.25^{1}$ \\
\hline & & $\mathrm{MAP}+\mathrm{PAD}$ & $1.90 \pm 0.91 \mathrm{~g}$ & $2.30 \pm 0.82 \mathrm{~h}$ & $1.80 \pm 0.79 \mathrm{~g}$ & $1.40 \pm 0.52 \mathrm{~g}$ & $100 \pm 0.32 \mathrm{j}$ & $1.70 \pm 0.30^{\mathrm{i}}$ \\
\hline & & PMAP - PAD & $1.00 \pm 0.01 \mathrm{k}$ & $2.20 \pm 0.63^{\mathrm{f}}$ & $1.00 \pm 0.67 \mathrm{k}$ & $1.00 \pm 0.01^{j}$ & $1.00 \pm 0.01 \mathrm{j}$ & $1.24 \pm 0.36^{\mathrm{k}}$ \\
\hline & & PMAP + PAD & $1.30 \pm 0.82^{j}$ & $3.30 \pm 0.48 \mathrm{e}$ & $1.20 \pm 0.42^{j}$ & $1.10 \pm 0.32^{\mathrm{i}}$ & $1.10 \pm 0.32^{\mathrm{i}}$ & $1.60 \pm 0.21 \mathrm{j}$ \\
\hline \multirow{6}{*}{6} & \multirow{4}{*}{0} & $\mathrm{MAP}-\mathrm{PAD}$ & $3.70 \pm 0.48 \mathrm{~b}$ & $2.10 \pm 0.74 \mathrm{e}$ & $3.70 \pm 0.67 \mathrm{~b}$ & $450 \pm 0.53 \mathrm{~b}$ & $4.70 \pm 0.48 \mathrm{~b}$ & $3.74 \pm 0.12 \mathrm{~b}$ \\
\hline & & $\mathrm{MAP}+\mathrm{PAD}$ & $4.10 \pm 0.57 \mathrm{a}$ & $4.80 \pm 0.42^{\mathrm{a}}$ & $4.70 \pm 0.48 \mathrm{a}$ & $4.60 \pm 0.52 \mathrm{a}$ & $4.80 \pm 0.42 \mathrm{a}$ & $4.60 \pm 0.06^{\mathrm{a}}$ \\
\hline & & PMAP - PAD & $2.80 \pm 0.67 \mathrm{~d}$ & $3.30 \pm 0.67^{c}$ & $1.40 \pm 0.52 \mathrm{f}$ & $1.80 \pm 0.42 \mathrm{f}$ & $1.70 \pm 0.68 \mathrm{f}$ & $2.20 \pm 0.11^{\mathrm{f}}$ \\
\hline & & $\mathrm{PMAP}+\mathrm{PAD}$ & $3.30 \pm 0.48^{c}$ & $4.10 \pm 0.57 \mathrm{~b}$ & $2.20 \pm 0.42 \mathrm{~d}$ & $2.20 \pm 0.42 \mathrm{e}$ & $1.80 \pm 0.42 \mathrm{e}$ & $2.72 \pm 0.06^{d}$ \\
\hline & \multirow[b]{2}{*}{4} & MAP - PAD & $2.40 \pm 0.52 \mathrm{e}$ & $1.70 \pm 0.68 \mathrm{f}$ & $2.10 \pm 0.57 \mathrm{e}$ & $240 \pm 0.52 \mathrm{~d}$ & $2.60 \pm 0.52 \mathrm{~d}$ & $2.24 \pm 0.07 \mathrm{e}$ \\
\hline & & $\mathrm{MAP}+\mathrm{PAD}$ & $2.40 \pm 0.52 \mathrm{e}$ & $3.20 \pm 0.42^{\mathrm{d}}$ & $2.30 \pm 0.48^{c}$ & $320 \pm 0.42^{c}$ & $2.90 \pm 0.32^{c}$ & $2.80 \pm 0.08^{c}$ \\
\hline \multirow{4}{*}{12} & \multirow{2}{*}{0} & MAP - PAD & $2.30 \pm 0.48 \mathrm{~b}$ & $1.50 \pm 0.85 c$ & $2.60 \pm 0.52 \mathrm{~b}$ & $290 \pm 0.74 b$ & $2.80 \pm 0.42 b$ & $2.42 \pm 0.18 \mathrm{~b}$ \\
\hline & & $\mathrm{MAP}+\mathrm{PAD}$ & $2.60 \pm 0.52 \mathrm{a}$ & $3.10 \pm 0.32 \mathrm{~d}$ & $3.20 \pm 0.42 \mathrm{a}$ & $3.10 \pm 0.32 \mathrm{a}$ & $310 \pm 0.32 \mathrm{a}$ & $3.02 \pm 0.09 \mathrm{a}$ \\
\hline & \multirow{2}{*}{4} & MAP - PAD & $1.00 \pm 0.01 \mathrm{~d}$ & $1.00 \pm 0.01 \mathrm{e}$ & $1.10 \pm 0.03 \mathrm{~d}$ & $140 \pm 0.52 \mathrm{~d}$ & $1.30 \pm 0.48 \mathrm{~d}$ & $1.16 \pm 0.25 \mathrm{~d}$ \\
\hline & & $\mathrm{MAP}+\mathrm{PAD}$ & $1.20 \pm 0.42 c$ & $2.40 \pm 0.70 \mathrm{~b}$ & $1.30 \pm 0.70 \mathrm{c}$ & $200 \pm 0.01 \mathrm{c}$ & $1.90 \pm 0.32 \mathrm{c}$ & $1.76 \pm 0.26 \mathrm{c}$ \\
\hline
\end{tabular}

Data are the means of scores of 10 panelists. Superscript alphabets are significant differences between each packaged fillet. Different letters indicate a significant difference in $\mathrm{pH}$ values $(p<0.05)$. MAP-pad $=$ active-MA without pads; MAP + PAD active-MA with pads; PMAP - PAD = passive-MA without pads; and PMAP + PAD = passive-MA with pads. Sampling was stopped on days when sensory spoilage was observed, thus sampling for fillets stored under MAP at $8{ }^{\circ} \mathrm{C}$ was stopped on day 3 ; similarly, sampling for fillets stored under PMAP at $4{ }^{\circ} \mathrm{C}$ and $8{ }^{\circ} \mathrm{C}$ was stopped on day 3 as well. Furthermore, sampling for fillets stored under PMAP at $0{ }^{\circ} \mathrm{C}$ was stopped on day 6 .

However, for active-MA packaged Cape hake fillets stored at $0{ }^{\circ} \mathrm{C}$, the shelf-life and overall acceptability were at maximum after 12 days. Lauzon et al. [23] obtained similar results in their study of unsalted cod fillets stored at $0{ }^{\circ} \mathrm{C}$ and $-2{ }^{\circ} \mathrm{C}$ in MAP $\left(\mathrm{CO}_{2} / \mathrm{O}_{2} / \mathrm{N}_{2}: 50 / 5 / 45\right)$. The authors also found that AMCs were below $5.5 \mathrm{log} \mathrm{cfu} / \mathrm{g}$ on day 12 but increased to $7.2 \log \mathrm{cfu} / \mathrm{g}$ on day 15 for fillets stored at $0{ }^{\circ} \mathrm{C}$. Based on these findings, Lauzon et al. [23] concluded that the produce shelf-life was 14 to 15 days at $0{ }^{\circ} \mathrm{C}$ and 21 days at $-2{ }^{\circ} \mathrm{C}$. The difference between the shelf-life at $0^{\circ} \mathrm{C}$ and our findings could be attributed to the microbial limits of $<5.5 \log \mathrm{cfu} / \mathrm{g}$ [70] used in our study, the geographical location, or since cod was used in the study. This study is consistent with literature as lower temperatures lead to greater dissolution of $\mathrm{CO}_{2}$ in fish tissues [51-53]. Furthermore, the higher $\mathrm{CO}_{2}$ levels led to an increase in the bacteriostatic ability at $0{ }^{\circ} \mathrm{C}[22,23]$.

\subsection{Correlation between Quality Indices}

Pearson correlation was conducted to explore the relationships between the investigated quality attributes of Cape hake fish (Table 3). Interesting significant relationships with varying correlation coefficients were obtained. A weakly negative relationship $(\mathrm{r}=-0.40)$ between work of shear and $\mathrm{pH}$ suggests that fillets stored in a weakly acidic ( $\mathrm{pH}$ 5.6-6.5) medium had better firmness quality than those stored in a basic ( $\mathrm{pH} \mathrm{7-8)} \mathrm{medium} \mathrm{(Table} \mathrm{3).}$ Results also showed that acidic medium (low $\mathrm{pH}$ ) could influence the color of fillets as evident by the positive correlation $(\mathrm{r}=0.43)$ between $\mathrm{pH}$ and the total color difference of fish fillets (Table 3). Although the relationship between $\mathrm{CO}_{2}$ levels and exudates was moderately positive $(r=0.52)$, with the strong negative correlation $(r=-0.78)$ between $\mathrm{CO}_{2}$ levels and aerobic mesophillic counts, it is reasonable to hypothesize that $\mathrm{CO}_{2}$ levels could minimize the effects of microbes on fish fillet. Another interesting relationship was the moderately negative correlation between work of shear and aerobic mesophillic counts $(r=-0.62)$, suggesting that fillet firmness would be maintained when microbial activity 
was minimal. This was also buttressed by the moderately positive correlations between the work of shear and all the sensory attributes, such as work of shear-color $(r=0.54)$, work of shear-freshness $(r=0.51)$, work of shear-fresh fish odor $(r=0.51)$, and work of shear-overall acceptability $(\mathrm{r}=0.52$; Table 3$)$. It is also noteworthy that $\mathrm{pH}$ showed negative correlations with most of the investigated sensory attributes, such as with color $(r=-0.43)$, firmness $(r=-0.39)$, freshness $(r=-0.48)$, fresh fish odor $(r=-0.45)$, and overall acceptability $(\mathrm{r}=-0.42$; Table 3$)$. This association suggests the importance of low $\mathrm{pH}$ in stored fish fillet in maintaining the color, firmness, freshness, fresh fish odor, and overall acceptability of Cape hake fillets.

Table 3. Pearson correlation coefficient matrix between quality indicators measured in Cape hake fillets during storage.

\begin{tabular}{|c|c|c|c|c|c|c|c|c|c|c|c|c|c|}
\hline Variables & $\mathrm{pH}$ & WS & DL & TCD & $\mathrm{O}_{2}$ & $\mathrm{CO}_{2}$ & AMC & Color & Exudate & Firmness & Freshness & Fresh Odor & OA \\
\hline \multirow{2}{*}{$\mathrm{pH}$} & \multirow[b]{2}{*}{1} & - & - & - & - & - & - & - & - & - & - & - & - \\
\hline & & - & - & - & - & - & - & - & - & - & - & - & - \\
\hline WS & -0.40 & 1 & - & - & - & - & - & - & - & - & - & - & - \\
\hline Drip loss & 0.19 & -0.194 & 1 & - & - & - & - & - & - & - & - & - & - \\
\hline TCD & 0.43 & -0.34 & 0.22 & 1 & - & - & - & - & - & - & - & - & - \\
\hline $\mathrm{O}_{2}$ & -0.27 & 0.77 & 0.07 & -0.36 & 1 & - & - & - & - & - & - & - & - \\
\hline $\mathrm{CO}_{2}$ & -0.25 & 0.17 & 0.29 & 0.37 & 0.36 & 1 & - & - & - & - & - & - & - \\
\hline AMC & 0.52 & -0.62 & 0.07 & 0.61 & -0.77 & -0.78 & 1 & - & - & - & - & - & - \\
\hline Color & -0.43 & 0.54 & -0.27 & -0.78 & 0.44 & -0.24 & -0.70 & 1 & - & - & - & - & - \\
\hline Exudate & -0.08 & 0.23 & 0.46 & -0.56 & 0.02 & 0.47 & -0.22 & 0.59 & 1 & - & - & - & - \\
\hline Firmness & -0.39 & 0.48 & -0.09 & -0.66 & 0.62 & 0.09 & -0.72 & 0.82 & 0.42 & 1 & - & - & - \\
\hline Freshness & -0.48 & 0.51 & -0.17 & -0.68 & -0.60 & 0.10 & -0.80 & 0.86 & 0.40 & 0.89 & 1 & - & - \\
\hline Fresh Odor & -0.45 & 0.51 & -0.15 & -0.65 & 0.61 & 0.15 & -0.77 & 0.82 & 0.32 & 0.90 & 0.97 & 1 & - \\
\hline $\mathrm{OA}$ & -0.42 & 0.52 & -0.27 & -0.76 & 0.52 & -0.09 & -0.73 & 0.94 & 0.63 & 0.92 & 0.95 & 0.920 & 1 \\
\hline
\end{tabular}

Correlation values in bold are significant at $p<0.05$. WS $=$ work of shear; DL $=$ drip loss; TCD $=$ total color difference; $\mathrm{AMC}=$ aerobic mesophillic count; and $\mathrm{OA}=$ overall acceptance.

Furthermore, strong negative correlations between aerobic mesophillic counts' AMCs and the sensory scores for color $(r=-0.70)$, firmness $(r=-0.72)$, freshness $(r=-0.80)$, fresh fish odor $(\mathrm{r}=-0.77)$, and overall acceptability $(\mathrm{r}=-0.73)$ were observed (Table 3$)$. The relationships imply that minimal microbial activity is also essential in maintaining the color, firmness, freshness, fresh fish odor, and overall acceptability quality attributes, which are desirable in Cape hake fillets. This is validated by the strong positive correlations observed between freshness and firmness $(r=0.89)$, fresh fish odor and firmness $(r=0.90)$, fresh fish odor and freshness $(r=0.97)$, overall acceptability and firmness $(r=0.92)$, overall acceptability and freshness $(r=0.95)$, and overall acceptability and fresh fish odor $(r=0.92)$.

\section{Conclusions}

The headspace gas compositions of $\mathrm{O}_{2}$ and $\mathrm{CO}_{2}$ were significantly influenced by the storage time, temperature, and packaging conditions, and their interactions. The level of $\mathrm{O}_{2}$ decreased continuously across all treatments and passive-MA packaged fillets reached about $2.7 \%$ on the 9 th day of storage. These results highlight the need for research to select appropriate packaging materials with desirable gas permeability properties in the design of MAP systems for RTC fish products.

Storage temperature, the use of absorbent pads, and MA had significant impacts on changes in the physicochemical properties of Cape hake fillets during storage $(p<0.05)$. Active-MA packaged fillets had lower $\mathrm{pH}$ values in comparison to fillets stored under passive-MA across all temperatures. Drip loss was higher in fillets packaged without absorbent pads. The use of pads, combined with low storage temperature, had a significant impact on the firmness of hake fillets across all temperatures $(p<0.05)$. Cape hake fillets stored at $0{ }^{\circ} \mathrm{C}$ maintained better firmness than those at higher storage temperatures. Based on the measured physicochemical, microbial, and sensory attributes, active-MAP $\left(40 \% \mathrm{CO}_{2}+30 \% \mathrm{O}_{2}+30 \% \mathrm{~N}_{2}\right)$ combined with low temperature $\left(0{ }^{\circ} \mathrm{C}\right)$ extended the shelflife and maintained the quality attributes of Cape hake fillets up to 12 days. 
These findings provide a useful guide for the fresh fish processing industry towards improving the post-harvest handling, packaging, and storage of Cape hake fillets and other fish products. The use of high-grade fillets, optimum processing and storage temperature regime, good agricultural practices, good hygienic practices, and correct gas composition is needed to achieve the best results with MAP. As MAP has achieved commercial acceptance over the years, active-MAP systems for handling fish can equally gain commercial acceptance and become viable. The integration of gas lines into existing processing and packing lines is practical and cost-effective. Under large-scale fish production, minimizing post-harvest and financial losses via shelf-life extension will provide additional economic benefits.

Supplementary Materials: The following supporting information can be downloaded at: https: / / www.mdpi.com/article/10.3390/coatings12030310/s1, Table S1: Effect of packaging with/without absorbent pads, temperature $\left(0,4\right.$, and $8{ }^{\circ} \mathrm{C}$ ) and storage time on firmness (work of shear $(\mathrm{N} / \mathrm{s})$ ) of Cape hake fillet; Table S2: Effects of packaging with/without absorbent pads (MAP + PAD, MAP $\mathrm{PAD}, \mathrm{PMAP}+\mathrm{PAD}$, and PMAP - PAD), temperature $\left(0,4\right.$, and $\left.8{ }^{\circ} \mathrm{C}\right)$, and storage time (3-12 days) on total color difference of Cape hake fillet; and Table S3: Effects of packaging with/without absorbent pads, temperature $\left(0,4\right.$, and $\left.8{ }^{\circ} \mathrm{C}\right)$, and storage time (days) on bacterial growth of Cape hake fillet.

Author Contributions: Conceptualization, U.L.O.; methodology, A.O.O. and O.J.C.; validation, A.O.O.; formal analysis, A.O.O.; writing-original draft preparation, A.O.O.; writing-review and editing, U.L.O., T.F., O.J.C. and A.O.O.; visualization, U.L.O., T.F., O.J.C. and A.O.O.; supervision, U.L.O. and O.J.C.; project administration, U.L.O.; funding acquisition, U.L.O. All authors have read and agreed to the published version of the manuscript.

Funding: This work is based on the research supported wholly by the National Research Foundation (NRF) of South Africa (Grant No. 64813). The opinions, findings, and conclusions or recommendations expressed are those of the author(s) alone and the NRF accepts no liability whatsoever in this regard.

Institutional Review Board Statement: Not applicable.

Informed Consent Statement: Not applicable.

Data Availability Statement: Not applicable.

Acknowledgments: The Agricultural Research Council of Nigeria, through the World Bank Project, for a postgraduate scholarship awarded to A.O.O.

Conflicts of Interest: The authors declare no conflict of interest.

\section{References}

1. Moreira, A.B.; Visentainer, J.V.; de Souza, N.E.; Matsushita, M. Fatty acids profile and cholesterol contents of three Brazilian Brycon freshwater fishes. J. Food Compos. Anal. 2001, 14, 565-574. [CrossRef]

2. Dave, D.; Routray, W. Current scenario of Canadian fishery and corresponding underutilized species and fishery by-products: A potential source of omega-3 fatty acids. J. Clean. Prod. 2018, 180, 617-641. [CrossRef]

3. Del Nobile, M.A.; Corbo, M.R.; Speranza, B.; Sinigaglia, M.; Conte, A.; Caroprese, M. Combined effect of modified atmosphere packaging and active compounds on fresh blue fish burger. Int. J. Food Microbiol. 2009, 135, 281-287. [CrossRef]

4. Pal, J.; Shukla, B.N.; Maurya, A.K.; Verma, H.O.; Pandey, G.; Amitha, A. A review on role of fish in human nutrition with special emphasis to essential fatty acid. Int. J. Fish. Aquat. Stud. 2018, 6, 427-430.

5. Kris-Etherton, P.M.; Harris, W.S.; Appel, L.J. Fish consumption, fish oil, omega-3 fatty acids, and cardiovascular disease. Circulation 2002, 106, 2747-2757. [CrossRef] [PubMed]

6. Trondsen, T.; Scholderer, J.; Lund, E.; Eggen, A.E. Perceived barriers to consumption of fish among Norwegian women. Appetite 2003, 41, 301-314. [CrossRef]

7. Domingo, J.L.; Bocio, A.; Falco, G.; Llobet, J.M. Benefits and risks of fish consumption: Part I. A quantitative analysis of the intake of omega-3 fatty acids and chemical contaminants. Toxicology 2007, 230, 219-226. [CrossRef]

8. AlAmmar, W.A.; Albeesh, F.H.; Ibrahim, L.M.; Algindan, Y.Y.; Yamani, L.Z.; Khattab, R.Y. Effect of omega-3 fatty acids and fish oil supplementation on multiple sclerosis: A systematic review. Nutr. Neurosci. 2021, 24, 569-579. [CrossRef] [PubMed]

9. Ekmekcioglu, C.; Wallner, P.; Kundi, M.; Weisz, U.; Haas, W.; Hutter, H.P. Red meat, diseases, and healthy alternatives: A critical review. Crit. Rev. Food Sci. Nutr. 2018, 58, 247-261. [CrossRef]

10. Béné, C.; Barange, M.; Subasinghe, R.; Pinstrup-Andersen, P.; Merino, G.; Hemre, G.I.; Williams, M. Feeding 9 billion by 2050-Putting fish back on the menu. Food Secur. 2015, 7, 261-274. [CrossRef] 
11. Obiero, K.; Meulenbroek, P.; Drexler, S.; Dagne, A.; Akoll, P.; Odong, R.; Kaunda-Arara, B.; Waidbacher, H. The contribution of fish to food and nutrition security in Eastern Africa: Emerging trends and future outlooks. Sustainability 2019, 11, 1636. [CrossRef]

12. Castrica, M.; Pavlovic, R.; Balzaretti, C.M.; Curone, G.; Brecchia, G.; Copelotti, E.; Panseri, S.; Pessina, D.; Arnoldi, C.; Chiesa, L.M. Effect of High-Pressure Processing on Physico-Chemical, Microbiological and Sensory Traits in Fresh Fish Fillets (Salmo salar and Pleuronectes platessa). Foods 2021, 10, 1775. [CrossRef] [PubMed]

13. Ahmed, A.A. Postharvest losses of fish in developing countries. Nutr. Health 2008, 19, 273-287. [CrossRef] [PubMed]

14. Food and Agricultural Organisation. World Review of Fisheries and Aquaculture Part 1. 2014. Available online: http://www.fao. org/docrep/013/i1820e/i1820e (accessed on 22 April 2021).

15. Socaciu, M.I.; Semeniuc, C.A.; Vodnar, D.C. Edible films and coatings for fresh fish packaging: Focus on quality changes and shelf-life extension. Coatings 2018, 8, 366. [CrossRef]

16. Dondero, M.; Cisternas, F.; Carvajal, L.; Simpson, R. Changes in quality of vacuum-packed cold-smoked salmon (Salmo salar) as a function of storage temperature. Food Chem. 2004, 87, 543-550. [CrossRef]

17. Bellagha, S.; Sahli, A.; Farhat, A.; Kechaou, N.; Glenza, A. Studies on salting and drying of sardine (Sardinella aurita): Experimental kinetics and modelling. J. Food Eng. 2007, 78, 947-952. [CrossRef]

18. De Silva, D.A.M.; Yamao, M. Regional preferences in the Japanese Seafood consumption: An empirical analysis of consumer purchasing behaviour on domestic versus imported seafood. Jpn. J. Reg. Fish. Soc. 2006, 46, 83-104.

19. Speranza, B.; Corbo, M.; Conte, A.; Sinigaglia, M.; Del Nobile, M. Microbiological and sensorial quality assessment of ready-tocook seafood products packaged under modified atmosphere. J. Food Sci. 2009, 74, M473-M478. [CrossRef]

20. Ordonez, J.A.; Lopez-Galvez, D.E.; Fernandez, M.; Hierro, E.; de la Hoz, L. Microbial and physicochemical modifications of hake (Merluccius merluccius) steaks stored under carbon dioxide enriched atmospheres. J. Sci. Food Agric. 2000, 80, 1831-1840. [CrossRef]

21. Erkan, N.; Ozden, Ö.; Inugur, M. The effects of modified atmosphere and vacuum packaging on quality of chub mackerel. Int. J. Food Sci.Technol. 2007, 42, 1297-1304. [CrossRef]

22. Sivertsvik, M. The optimized modified atmosphere for packaging of pre- rigor filleted farmed cod (Gadus morhua) is $63 \mathrm{~mL} / 100 \mathrm{~mL}$ oxygen and $37 \mathrm{~mL} / 100 \mathrm{~mL}$ carbon dioxide. LWT Food Sci. Technol. 2007, 40, 430-438. [CrossRef]

23. Lauzon, H.L.; Magnusson, H.; Sveinsdottir, K.; Gudjonsdottir, M.; Martinsdottir, E. Effect of brining, modified atmosphere packaging, and super-chilling on the shelf-life of cod (Gadus morhua) loins. J. Food Sci. 2009, 74, 258-267. [CrossRef] [PubMed]

24. Yesudhason, P.; Gopal, T.K.S.; Ravi Shankar, C.N.; Lalitha, K.V.; Kumar, K.N.A. Effect of modified atmosphere packaging on chemical, textural, microbiological and sensory quality of seer fish (Scomberomorus commerson) steaks packaged in thermo-formed trays at $0-2{ }^{\circ} \mathrm{C}$. J. Food Process. Preserv. 2009, 33, 777-797. [CrossRef]

25. Caglak, E.; Cakli, S.; Kilinc, B. Effect of modified atmosphere packaging on quality and shelf-life of salted bonito (Sarda sarda). J. Aquat. Food Prod. Technol. 2012, 21, 206-221. [CrossRef]

26. Angis, S.; Oguzhan, P. Effect of thyme essential oil and packaging treatments on chemical and microbiological properties of fresh rainbow trout (Oncorhynchus mykiss) fillets during storage at refrigerator temperatures. Afr. J. Microbiol. Res. 2013, 7, 1136-1143.

27. Lekjing, S.; Venkatachalam, K. Effects of modified atmospheric packaging conditions on the quality changes of pasteurized oyster (Crassostrea belcheri) meat during chilled storage. J. Aquat. Food Prod. Technol. 2018, 27, 1106-1119. [CrossRef]

28. Sáez, M.I.; Martínez, T.F.; Cárdenas, S.; Suárez, M.D. Effects of vacuum and modified atmosphere on textural parameters and structural proteins of cultured meagre (Argyrosomus regius) fillets. Food Sci. Technol. Int. 2015, 21, 467-478. [CrossRef]

29. Hernández, E.J.G.P.; de Carvalho, R.N., Jr.; Joele, M.R.S.P.; da Silva Araújo, C.; Lourenço, L.D.F.H. Effects of modified atmosphere packing over the shelf life of sous vide from captive pirarucu (Arapaima gigas). Innov. Food Sci. Emerg. Technol. 2017, 39, 94-100. [CrossRef]

30. Zhang, J.; Li, Y.; Liu, X.; Lei, Y.; Regenstein, J.M.; Luo, Y. Characterization of the microbial composition and quality of lightly salted grass carp (Ctenopharyngodon idellus) fillets with vacuum or modified atmosphere packaging. Int. J. Food Microbiol. 2019, 293, 87-93. [CrossRef]

31. Lázaro, C.A.; Monteiro, M.L.G.; Conte-Junior, C.A. Combined effect of modified atmosphere packaging and UV-C radiation on pathogens reduction, biogenic amines, and shelf life of refrigerated tilapia (Oreochromis niloticus) Fillets. Molecules 2020, 25, 3222. [CrossRef]

32. Olatunde, O.O.; Benjakul, S.; Vongkamjan, K. Comparative study on nitrogen and argon-based modified atmosphere packaging on microbiological, chemical, and sensory attributes as well as on microbial diversity of Asian sea bass. Food Packag. Shelf Life 2019, 22, 100404. [CrossRef]

33. Wang, Z.C.; Yan, Y.; Fang, Z.; Nisar, T.; Sun, L.; Guo, Y.; Xia, N.; Wang, H.; Chen, D.W. Application of nitric oxide in modified atmosphere packaging of tilapia (Oreschromis niloticus) fillets. Food Control 2019, 98, 209-215. [CrossRef]

34. Esteves, E.; Guerra, L.; Aníbal, J. Effects of vacuum and modified atmosphere packaging on the quality and shelf-life of gray triggerfish (Balistes capriscus) fillets. Foods 2021, 10, 250. [CrossRef] [PubMed]

35. Pathare, P.B.; Opara, U.L.; Al-Said, F.A.J. Colour measurement and analysis in fresh and processed foods: A review. Food Bioproc. Tech. 2013, 6, 36-60. [CrossRef]

36. Chen, L.; Opara, U.L. Texture measurement approaches in fresh and processed foods-A review. Food Res. Int. 2013, 51, 823-835. [CrossRef] 
37. Chen, L.; Opara, U.L. Approaches to analysis and modeling texture in fresh and processed foods-A review. J. Food Eng. 2013, 119, 497-507. [CrossRef]

38. Cheng, J.; Sun, D.W.; Zeng, X.A.; Liu, D. Recent advances in methods and techniques for freshness quality determination and evaluation of fish and fish fillets: A review. Crit. Rev. Food Sci. Nutr. 2014, 13, 52-61. [CrossRef]

39. Goulas, A.E.; Kontominas, M.G. Combined effect of light salting, modified atmosphere packaging and oregano essential oil on the shelf-life of sea bream (Sparus aurata): Biochemical and sensory attributes. Food Chem. 2007, 100, 287-296. [CrossRef]

40. Da Silva, N.; Taniwaki, M.H.; Junqueira, V.C.; Silveira, N.; Do Nascimento, M.D.S.; Gomes, R.A.R. Microbiological Examination Methods of Food and Water. A Laboratory Manual; CRC Press: Washington, DC, USA, 2012.

41. SANS. Method 4833. Microbiology: General Guidance for the Enumeration of Microorganisms—Colony Count Technique at $30{ }^{\circ} \mathrm{C}, 2 \mathrm{nd}$ ed.; South African Bureau of Standards: Pretoria, South Africa, 2007.

42. Hara-Kudo, Y.; Sugiyama, K.; Nishibuchi, M.; Chowdhury, A.; Yatsuyanagi, J.; Ohtomo, Y.; Kumagai, S. Prevalence of pandemic thermo stable direct haemolysin-producing Vibrio parahaemolyticus O3: K6 in seafood and the coastal environment in Japan. J. Appl. Environ. Microbiol. 2003, 69, 3883-3891. [CrossRef]

43. ISO 21528-2; Microbiology of Food and Animal Feeding Stuffs Horizontal Methods for the Detection and Enumeration of Enterobacteriaceae-Part 2: Colony Count Method. 1st ed. International Organization for Standardization: Geneva, Switzerland, 2004.

44. ISO/TS 21872-1; Microbiology of Food and Animal Feeding Stuffs. Horizontal Method for the Detection of Potentially EnteroPathogenic Vibrio spp. Part 1: Detection of Vibrio parahaemolyticus and Vibrio cholera. International Organization for Standardization: Geneva, Switzerland, 2007.

45. AOAC International. Official Methods of Analysis, 18th ed.; Current through revision 2, 2007 (Online). Method 960.52 (MicroKjeldahl method) and Method 981.10 (crude protein in meat and meat products); The Association of Official Analytical Chemists: Gaithersburg, MD, USA, 2007.

46. AOAC International-Association of Official Analytical Chemists. Official Methods of Analysis, 17th ed.; AOAC International: Arlington, VA, USA, 2000.

47. AOAC International. Loss on drying (moisture) at $95-100{ }^{\circ} \mathrm{C}$ for feeds. In Official Methods of Analysis, 17th ed.; AOAC Official Method 934.01; Association of Official Analytical Chemists Inc.: Arlington, VA, USA, 2002.

48. AOAC International. Ash of Animal Feed. In Official Methods of Analysis, 17th ed.; AOAC Official Method 942.05; Association of Official Analytical Chemists Inc: Arlington, VA, USA, 2002.

49. Ivanov, G.; Balev, D.; Nikolov, H.; Dragoev, S. Improvement of chilled salmon sensory quality by pulverisation with natural di-hydro-quercetin solutions. Bulg. J. Agric. Sci. 2009, 15, 154-162.

50. Masniyom, P. Deterioration and shelf-life extension of fish and fishery products by modified atmosphere packaging. Songklanakarin J. Sci. Technol. 2011, 33, 181-192.

51. Ruiz-Capillas, C.; Moral, A. Chilled bulk storage of gutted hake (Merluccius merluccius,) in carbon dioxide and oxygen enriched controlled atmospheres. Food Chem. 2001, 74, 317-325. [CrossRef]

52. Sivertsvik, M.; Rosnes, J.T.; Jeksrud, W.K. Solubility and absorption rate of carbon dioxide into non-respiring foods. Part 2: Raw fish fillets. J. Food Eng. 2004, 63, 451-458. [CrossRef]

53. Torrieri, E.; Cavella, S.; Villani, F.; Masi, P. Influence of modified atmosphere packaging on the chilled shelf-life of gutted farmed bass (Dicentrarchus labrax). J. Food Eng. 2006, 77, 1078-1086. [CrossRef]

54. Sivertsvik, M.; Jeksrud, W.K.; Rosnes, J.T. A review of modified atmosphere packaging of fish and fishery products-significance of microbial growth, activities and safety. Int. J. Food Sci. Technol. 2002, 37, 107-127. [CrossRef]

55. Cyprian, O.; Oduor-Odote, P.; Lauzon, H.; Martinsdottir, E.; Arason, S. Microbiological quality and shelf life of fresh packaged tilapia fillets stored under different chill temperatures. J. Microbiol. Biotechnol. Food Sci. 2013, 2, 2431-2455.

56. Wang, T.; Sveinsdottir, K.; Magnusson, H.; Martinsdottir, E. Combined application of modified atmosphere packaging and super-chilled storage to extend the shelf life of fresh cod (Gadus morhua) loins. J. Food Sci. 2008, 73, 11-19. [CrossRef]

57. Stamatis, N.; Arkoudelos, J. Quality assessment of Scomber colias japonicas under modified atmosphere and vacuum packaging. Food Control 2007, 18, 292-300. [CrossRef]

58. Careche, M.; Del Mazo, M.L.; Fernandez-Martín, F. Extractability and thermal stability of frozen hake (Merluccius merluccius) fillets stored at $-10^{\circ} \mathrm{C}$ and $-30^{\circ} \mathrm{C}$. J. Sci. Food Agric. 2002, 1791-1799. [CrossRef]

59. Pacheco-Aguilar, R.; Lugo-Sanchez, M.E.; Robles-Burgueno, M.R. Post-mortem biochemical and functional characteristic of Monterey sardine muscle stored at $0{ }^{\circ} \mathrm{C}$. J. Food Sci. 2000, 65, 40-47. [CrossRef]

60. Fletcher, G.C.; Summers, G.; Corrigan, V.K.; Johanson, M.R.; Hedderley, D. Optimizing gas mixtures for modified atmosphere packaging of fresh king salmon (Oncorhynchus tshawytscha). J. Aquat. Food Prod. Technol. 2004, 13, 5-28. [CrossRef]

61. Soccol, M.H.; Oetterer, M. Use of modified atmosphere in seafood preservation. Braz. Arch. Biol. Technol. 2003, 46, 569-580. [CrossRef]

62. Ayala, M.D.; Santaella, M.; Martınez, C.; Periago, M.J.; Blanco, A.; Vazquez, J.M.; Albors, O.L. Muscle tissue structural changes and texture development in sea bream (Sparus aurata) during post-mortem storage. LWT Food Sci. Technol. 2010, 43, 465-475. [CrossRef]

63. Roth, B.; Birkeland, S.; Oyarzun, F. Stunning, pre slaughter and filleting conditions of Atlantic salmon and subsequent effect on flesh quality on fresh and smoked fillets. Aquaculture 2009, 289, 350-356. [CrossRef] 
64. Duun, A.S.; Rustad, T. Quality of super-chilled vacuum-packed Atlantic salmon (Salmo salar) fillets stored at -1.4 and $-3.6^{\circ} \mathrm{C}$. Food Chem. 2008, 106, 122-131. [CrossRef]

65. Hultmann, L.; Rustad, T. Iced storage of Atlantic salmon (Salmo salar)—Effects on endogenous enzymes and their impact on muscle proteins and texture. Food Chem. 2004, 87, 31-41. [CrossRef]

66. Regost, C.; Jakobsen, J.V.; Rora, A.M.B. Flesh quality of raw and smoked fillets of Atlantic salmon as influenced by dietary oil sources and frozen storage. Food Res. Int. 2004, 37, 259-271. [CrossRef]

67. Mancini, R.A.; Hunt, M.C. Current research in meat colour. Meat Sci. 2005, 71, 100-121. [CrossRef]

68. Sone, I.; Olsen, R.L.; Heia, K. Spectral changes of Atlantic salmon (Salmo salar) muscle during cold storage as affected by the oxidation state of heme. J. Agric. Food Chem. 2012, 60, 9719-9726. [CrossRef]

69. Chaijan, M.; Benjakul, S.; Visessanguan, W.; Faustman, C. Changes of pigments and colour in sardine (Sardinella gibbosa) and mackerel (Rastrelliger kanagurta) muscle during iced storage. Food Chem. 2005, 93, 607-617. [CrossRef]

70. HPA-Health Protection Agency. Guidelines for Assessing the Microbiological Safety of Ready-to-Eat Foods; Health Protection Agency: London, UK, 2009.

71. Arashisar, S.; Hisar, O.; Kaya, M.; Yanik, T. Effects of modified atmosphere and vacuum packaging on microbiological and chemical properties of rainbow trout (Oncorynchus mykiss) fillets. Int. J. Food Microbiol. 2004, 97, 209-214. [CrossRef] [PubMed] 